\title{
Resource use and efficiency, and stomatal responses to environmental drivers of oak and pine species in an Atlantic Coastal Plain forest
}

\section{OPEN ACCESS}

Edited by:

José M. Grünzweig,

The Hebrew University of Jerusalem,

Israel

Reviewed by:

Tamir Klein,

University of Basel, Switzerland

Rafael Poyatos,

Centre de Recerca Ecològica i

Aplicacions Forestals, Spain

Nadine Ruehr,

Karlsruhe Institute of Technology,

Germany

*Correspondence:

Heidi Renninger,

Department of Forestry,

Mississippi State University,

Thompson Hall, Box 9681, Mississippi

State, MS 39762, USA

heidi.renninger@msstate.edu

${ }^{\dagger}$ Present Address:

Heidi J. Renninger,

Department of Forestry,

Mississippi State University,

Mississippi State, USA

Specialty section: This article was submitted to Functional Plant Ecology, a section of the journal Frontiers in Plant Science

Received: 16 January 2015 Accepted: 13 April 2015

Published: 07 May 2015

Citation:

Renninger HJ, Carlo NJ, Clark KL and Schäfer KVR (2015) Resource use and efficiency, and stomatal responses to environmental drivers of oak and pine

species in an Atlantic Coastal Plain forest. Front. Plant Sci. 6:297. doi: 10.3389/fpls.2015.00297

\section{Heidi J. Renninger ${ }^{1 \star t}$, Nicholas J. Carlo ${ }^{2}$, Kenneth L. Clark ${ }^{3}$ and Karina V. R. Schäfer ${ }^{1,2}$}

${ }^{1}$ Department of Biological Sciences, Rutgers, The State University of New Jersey, Newark, NJ, USA, ${ }^{2}$ Department of Earth and Environmental Sciences, Rutgers, The State University of New Jersey, Newark, NJ, USA, ${ }^{3}$ Silas Little Experimental

Forest, Northern Research Station, United States Department of Agriculture Forest Service, New Lisbon, NJ, USA

Pine-oak ecosystems are globally distributed even though differences in anatomy and leaf habit between many co-occurring oaks and pines suggest different strategies for resource use, efficiency and stomatal behavior. The New Jersey Pinelands contain sandy soils with low water- and nutrient-holding capacity providing an opportunity to examine trade-offs in resource uptake and efficiency. Therefore, we compared resource use in terms of transpiration rates and leaf nitrogen content and resource-use efficiency including water-use efficiency (WUE) via gas exchange and leaf carbon isotopes and photosynthetic nitrogen-use efficiency (PNUE) between oaks (Quercus alba, Q. prinus, Q. velutina) and pines (Pinus rigida, P. echinata). We also determined environmental drivers [vapor pressure deficit (VPD), soil moisture, solar radiation] of canopy stomatal conductance $\left(G_{S}\right)$ estimated via sap flow and stomatal sensitivity to light and soil moisture. Net assimilation rates were similar between genera, but oak leaves used about $10 \%$ more water and pine foliage contained about 20\% more $N$ per unit leaf area. Therefore, oaks exhibited greater PNUE while pines had higher WUE based on gas exchange, although WUE from carbon isotopes was not significantly different. For the environmental drivers of $\mathrm{G}_{S}$, oaks had about $10 \%$ lower stomatal sensitivity to VPD normalized by reference stomatal conductance compared with pines. Pines exhibited a significant positive relationship between shallow soil moisture and $G_{S}$, but only $G_{S}$ in Q. velutina was positively related to soil moisture. In contrast, stomatal sensitivity to VPD was significantly related to solar radiation in all oak species but only pines at one site. Therefore, oaks rely more heavily on groundwater resources but have lower WUE, while pines have larger leaf areas and nitrogen acquisition but lower PNUE demonstrating a trade-off between using water and nitrogen efficiently in a resource-limited ecosystem.

Keywords: photosynthesis, canopy conductance, sap flow, nitrogen-use efficiency, water-use efficiency

\section{Introduction}

Forest ecosystems dominated by pines and oaks are distributed globally (Richardson and Rundel, 1998; Nixon, 2006) including locations in the Eastern United States (Nowacki and Abrams, 2008), Southwestern North and Central America (Kolb and Stone, 2000; 
Gómez-Mendoza and Arriaga, 2007), the Mediterranean (Guehl et al., 1995; Díaz, 2006), and Alpine Europe (Weber et al., 2007; Zweifel et al., 2007; Sterck et al., 2008; Eilmann et al., 2009). Pine-oak forests tend to occur in water-limited systems where either strong seasonality of precipitation or well-drained, sandy soils limit the occurrence of more mesic species (Nowacki and Abrams, 2008). Likewise, pine-oak forests are maintained in areas where fire is prevalent either naturally or as a management strategy (Parshall et al., 2003; Neill et al., 2007; Scheller et al., 2008) with pines being more successful under shorter fire return intervals and oaks being successful if fire is excluded from the system (Scheller et al., 2008). Even though oaks and pines inhabit many of the same ecosystems, they differ in terms of leaf type and hydraulic systems with oaks having larger leaves that are deciduous in many species and relying on large-diameter vessels with high hydraulic conductivity for water transport. Pines, on the other hand, have small, evergreen needle-like leaves and rely on smaller diameter tracheids for water transport. These large differences in leaf habit and water transport capacity of co-occurring oaks and pines could suggest that they have different strategies for obtaining and using nutrients and water, particularly in ecosystems with sandy soils that exhibit low waterand nutrient-holding capacity in the upper soil layers.

The sandy soils of the New Jersey Pinelands on the Atlantic Coastal Plain provide the ideal opportunity to compare strategies of water and nutrient use between oaks and pines in a resourcelimited ecosystem that may result from their differences in leaf morphology, leaf habit and water transport properties. In particular, using both water and nutrients efficiently should be important for oaks and pines in ecosystems where resources are limiting. The edaphic features of this ecosystem also provide the opportunity to study tradeoffs between using water or using nutrients efficiently both within each genus and between genera. Water-use efficiency (WUE) and photosynthetic nitrogen-use efficiency (PNUE) describe the amount of water transpired or $\mathrm{N}$ content per unit leaf area, respectively, for a given rate of photosynthetic assimilation. Several studies have found an inverse relationship between PNUE and WUE (Field et al., 1983) across species within a common ecosystem (DeLucia and Schlesinger, 1991), across tree size (Nabeshima and Hiura, 2004), or along a latitudinal gradient (Sheng et al., 2011). Indeed, we would expect trees to experience a trade-off between water- and nitrogen-use efficiency in ecosystems with sandy soils because a reliable source of water will be found in the deeper soil layers while much of the available nitrogen will be located near the surface in the decomposing litter layer. This spatial segregation of resources could mean that optimizing uptake of one resource occurs at the expense of the other. Likewise, stomatal conductance, which affects the rate of carbon dioxide influx into leaves and evaporation of water vapor out of leaves, provides a link between WUE and PNUE. Individuals with lower stomatal conductance may have higher WUE, but the lower concentration of carbon dioxide within leaves may decrease PNUE. Alternatively, decreased nitrogen content in leaves may lead to higher PNUE while making stomatal conductance less efficient, thereby decreasing WUE. Therefore, both WUE and PNUE are important for trees to achieve optimal productivity in resource-limited environments with each determined by both resource availability and competitive acquisition rates of each tree type.

The anatomical and physiological differences between oaks and pines could suggest that these tree types differ in resource acquisition strategies for water and nutrients. In terms of hydraulic architecture, McCulloh et al. (2010) found that, among various tree types, ring-porous species like oaks had the highest leaf-specific hydraulic conductivity, the fewest vessels per unit sapwood area and the greatest taper in their vascular network (which aids in offsetting effects of increasing path length as trees grow taller) while conifers, like pines, had the lowest leaf-specific conductivity, the highest proportion of conduits per unit sapwood area and the lowest taper in the vascular network, making water transport more size-dependent. However, Poyatos et al. (2008) found that Pinus sylvestris (L.) had higher leaf specific hydraulic conductance than co-occurring Quercus pubescens (Willd.) growing in a Mediterranean climate. In terms of stomatal regulation of water transport, in a global synthesis study, Choat et al. (2012) found that conifers had the largest "safety margin" between minimum in situ water potential and the water potential at which $50 \%$ of hydraulic conductivity is lost to embolism. On the other hand, several studies have found that oaks and other ring-porous species tend to be more anisohydric, exhibiting increasingly more negative leaf water potentials with increasing evaporative demand and drought stress (CavenderBares and Bazzaz, 2000; Zweifel et al., 2007; Poyatos et al., 2008; Klein et al., 2013; Meinzer et al., 2013). However, in a synthesis study, Martínez-Vilalta et al. (2014) sought to use the empirical relationship between predawn and midday leaf water potentials to directly compare isohydric/anisohydric behavior across species and ecosystem types and found that oaks and pines had similar behavior [Supplementary Material; Martínez-Vilalta et al. (2014)] with both genera considered "partial isohydric." In terms of nutrient acquisition, oaks tend to have higher foliar $\mathrm{N}$ concentrations than pines within the same ecosystem (Bockheim and Leide, 1991; Kolb and Stone, 2000; García-Barrios and González-Espinosa, 2004). Also, based on tradeoffs between leaf lifespan and leaf mass per unit area (LMA) vs. productivity and nutrient content, evergreen pines should have higher LMA, lower productivity and lower nutrient content than shorter-lived deciduous oak leaves (Wright et al., 2004). Therefore, although differences in anatomy and leaf habit are evident between pines and oaks, results from previous studies are mixed with regard to how these differences will affect physiological functioning of each genus in a resource-limited environment.

This study sought to compare resource use and efficiency as well as stomatal responses to environmental drivers of the dominant oak and pine species in the New Jersey Pinelands National Reserve located within the Atlantic Coastal Plain. The study area consists of sandy soils that tend to be excessively well-drained having low water holding capacity and nutrient retention. Due to these conditions, both WUE and PNUE should be important in order for species to successfully compete and our objective was to compare resource acquisition and resource use efficiency between oaks and pines to determine the trade-offs in resource-use strategies both within each genus 
and when comparing across genera. Likewise, because stomatal conductance is one of the controlling factors in both WUE and PNUE, our second objective was to determine the relationships between canopy stomatal conductance and its environmental controls including vapor pressure deficit (VPD), soil moisture and photosynthetic photon flux density (PPFD) in oaks and pines. Specifically, we hypothesize that (1) pines, with their evergreen leaf habit and water transport system that is reliant on small tracheids, will exhibit higher PNUE and WUE compared to oaks and (2) oaks will exhibit greater stomatal conductances than pines and will be less responsive to environmental conditions in accordance with an anisohydric stomatal habit. A more complete understanding of photosynthetic capacity and stomatal dynamics in both oaks and pines will help to elucidate how oakdominated, pine-dominated, and mixed forests function given environmental constraints, and will allow for more accurate modeling of forest carbon sequestration processes and water use given future climate change as well as changes in disturbance regimes.

\section{Materials and Methods}

\section{Site Descriptions}

Sites were located within the 470,000 ha New Jersey Pinelands National Reserve (Figure 1) which includes upland forests composed of $46 \%$ oak-dominated forests, 31\% oak-pine mixed forests, and $23 \%$ pine-dominated forests (Lathrop and Kaplan, 2004). Soils in the region are sandy and well-drained with limited nutrient-holding capacity and the site receives about $1100 \mathrm{~mm}$ of yearly precipitation. The site is cool temperate with average summer temperatures of approximately $22.7^{\circ} \mathrm{C}$ and average winter temperatures of approximately $1.3^{\circ} \mathrm{C}$ [www.ameriflux.ornl.gov; Clark et al. (2012)]. Due to the dry soil and litter layer conditions, wildfires tend to be prevalent (Little, 1979) and as a result, prescribed burning is routinely performed

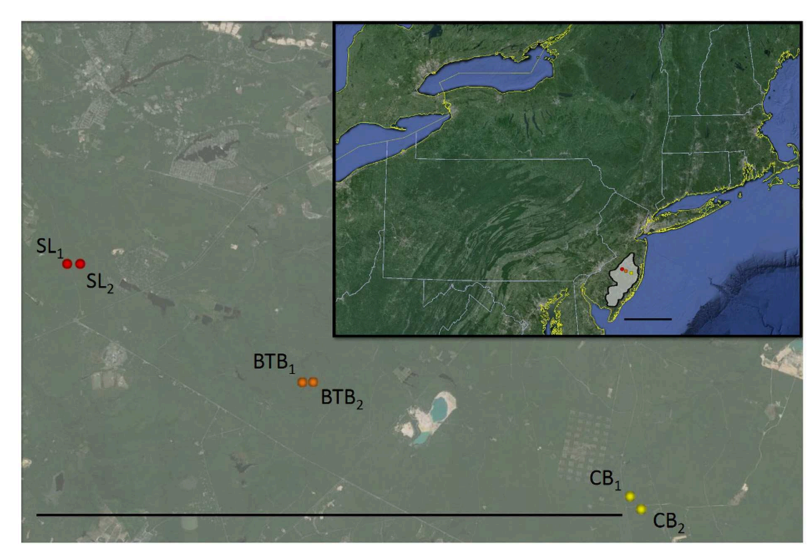

FIGURE 1 | Location of the New Jersey Pinelands National Reserve (in inset, shaded in gray; scale bar $=100 \mathrm{~km}$ ) and locations of Silas Little (SL; in red), Brendan T Byrne (BTB; in orange), and Cedar Bridge (CB; in yellow) sites. Scale bar on magnified map $=20 \mathrm{~km}$. Map data: Image NOAA, Image Landsat, Data SIO, NOAA, U.S. Navy, NGA, GEBCO, (c) 2015 Google. in late winter/early spring to reduce the risk of wildfires. Therefore, at each site, trees in both recently burned and unburned stands were pooled in order to capture the variability across the landscape due to the prescribed fire management. For more information on specific physiological differences resulting from prescribed fire, see Renninger et al. (2013). The summer growing season tends to be warm and humid with all months receiving moderate rainfall (June averages about $90 \pm 6 \mathrm{~mm}$ of rainfall, July about $116 \pm 7 \mathrm{~mm}$ and August about $130 \pm 9 \mathrm{~mm}$; www.ncdc.noaa.gov).

\section{SL Site}

Measurements were made within the United States Department of Agriculture Forest Service Silas Little Experimental Forest (Rutgers Pinelands Research Station; $39^{\circ} 51^{\prime} 57^{\prime \prime} \mathrm{N}, 74^{\circ} 35^{\prime} 46^{\prime \prime}$ $\mathrm{W}$; referred to below as the "SL" site) in two stands (Figure 1), one of which was burned in a prescribed fire in March, 2012. This site is an oak-dominated stand with the dominant tree species consisting of mainly chestnut oak (Quercus prinus L.) and black oak (Quercus velutina Lam.) with scattered scarlet oak (Quercus coccinea Muenchh.), white oak (Quercus alba L.), post oak (Quercus stellata Wangenh.), pitch pine (Pinus rigida Mill.), and shortleaf pine (Pinus echinata Mill.). Maximum canopy height is approximately $19.5 \mathrm{~m}$, stand age is 99 years and stand basal area is $17.6 \mathrm{~m}^{2} \mathrm{ha}^{-1}$ (Renninger et al., 2014; Skowronski et al., 2014). This study focused on the predominant oak species in this forest (Q. prinus, Q. velutina and Q. alba). All Quercus spp. study individuals were measured at this site as well as overstory Pinus spp. individuals. The understory is composed of mainly huckleberry and blueberry shrubs (Vaccinium and Gaylussacia sp.), bracken fern (Pteridium aquilinum L. Kuhn), sedges, mosses, and lichens. This site was defoliated by gypsy moths (Lymantria dispar L.) in the summers of 2007 and 2008 and information about its effects can be found in Clark et al. (2012) and Schäfer et al. (2010). Depth to groundwater is approximately $7 \mathrm{~m}$ at this site (Schäfer et al., 2014; United States Geological Survey http://waterdata.usgs.gov/nwis/).

\section{BTB Site}

Pinus rigida individuals were measured at two pine-dominated stands within the Brendan T. Byrne State Forest (Figure 1; $39^{\circ}$ $53^{\prime} \mathrm{N}, 74^{\circ} 30^{\prime} \mathrm{W}$; subsequently referred to as the "BTB” site). One stand was burned in a prescribed fire in March, 2011. Both stands are composed primarily of pitch pine with scattered overstory oak species including white oak, chestnut oak and black oak. Maximum canopy height is approximately $12.5 \mathrm{~m}$ and stand basal area is about $26.9 \mathrm{~m}^{2} \mathrm{ha}^{-1}$ (Renninger et al., 2013). The understory consists of scrub oaks (Q. marilandica Muenchh., $Q$. ilicifolia Wangenh.) blueberry and huckleberry shrubs, bracken fern, sedges, mosses, and lichens. Depth to groundwater is approximately $7.3 \mathrm{~m}$ at this site (United States Geological Survey site: 395234074302501 051587-Mb Up-2; http://waterdata.usgs. gov/nwis/).

\section{CB Site}

Pinus rigida individuals were also measured at two stands located in the Greenwood Wildlife Management Area near the Cedar 
Bridge Fire Tower (Figure 1; $39^{\circ} 49^{\prime} 4.19^{\prime \prime} \mathrm{N}, 74^{\circ} 22^{\prime} 32.28^{\prime \prime} \mathrm{W}$; subsequently referred to as the "CB" site). One stand was burned in a prescribed fire in March, 2013 (Clark et al., 2014). The stands are pine-dominated, with pitch pine in the overstory and white oak and scrub oaks in the understory. Maximum canopy height is approximately $12 \mathrm{~m}$, stand age is 90 years, and basal area is 14.3 $\mathrm{m}^{2} \mathrm{ha}^{-1}$ (Clark et al., 2012). The understory is also composed of blueberry and huckleberry shrubs, bracken fern, sedges, mosses and lichens. Depth to groundwater is approximately $21 \mathrm{~m}$ at this site (United States Geological Survey site: 394949074202901 290789-Cedar Brg Twr1; http://waterdata.usgs.gov/nwis/).

\section{Environmental Data}

At each site, meteorological and edaphic parameters were measured throughout the study period (Figures 2A,B). Temperature and relative humidity were measured using Vaisala HMP45C sensors (Campbell Scientific Inc., Logan UT, USA) located in the mid-canopy of each forest and used to calculate VPD following Goff and Gratch (1946). Precipitation and throughfall were measured with Texas Electronics TE525M tipping buckets (Campbell Scientific Inc.) and soil moisture content in the upper $0.3 \mathrm{~m}$ of the soil was measured in four locations at each site using CS616 sensors (Campbell Scientific Inc.). All sensors were attached to dataloggers (Campbell Scientific Inc.) located in each site that collected data every $30 \mathrm{~s}$ and averaged data every $30 \mathrm{~min}$. Photosynthetic photon flux density (PPFD) was measured at the SL and CB sites with LI-190SB quantum sensors (LI-COR Biosciences Inc., Lincoln NE, USA) located above each canopy on a tower (Clark et al., 2012).

\section{Leaf Gas Exchange}

Leaf gas exchange was measured at the BTB site in 2011, 2012, and 2013 and at the SL and CB sites in 2012 and 2013 using a LI-COR $6400 \mathrm{XT}$ photosynthesis system (LI-COR Biosciences Inc.) with a red/blue light source attached. For each individual during each measurement period, both light response and net assimilation to internal $\mathrm{CO}_{2}$ concentration $\left(A / C_{\mathrm{i}}\right)$ curves were

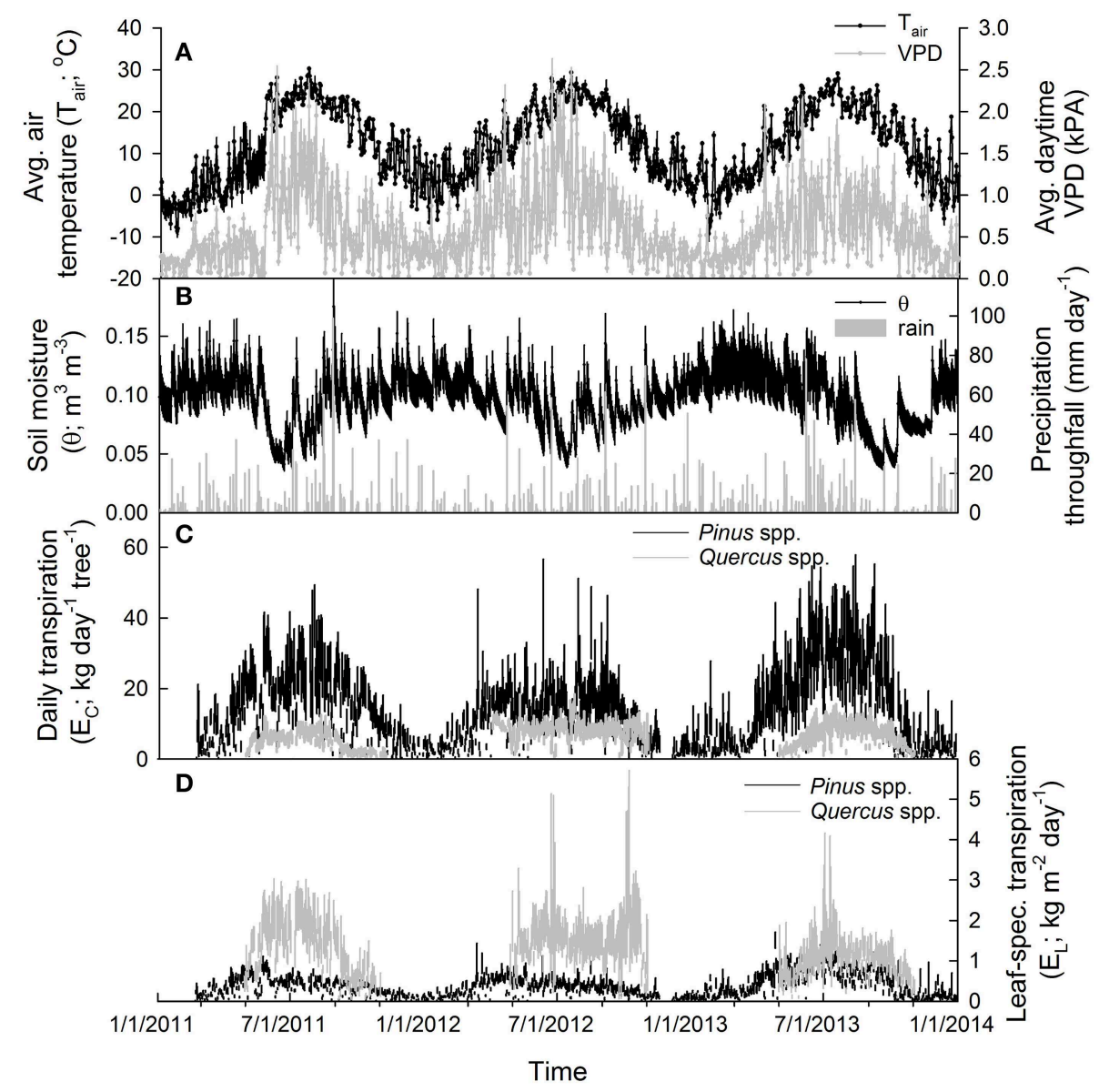

FIGURE 2 | Environmental and transpiration data (averaged across all sites) during the 2011-2013 study period, including (A) average daily air temperature (mean $\pm \mathrm{SE}$; ${ }^{\circ} \mathrm{C}$ ) and average daytime vapor pressure deficit (VPD; mean $\pm \mathrm{SE}$; $\mathrm{kPa}$ ) (B) average daily soil moisture (mean $\pm S E ; \mathrm{m}^{3} \mathrm{~m}^{-3}$ ) in the top $30 \mathrm{~cm}$ and total daily throughfall ( $\mathbf{m m} \mathbf{d a y}^{\mathbf{- 1}}$ ). (C) Total daily tree-level transpiration $\left(\mathrm{E}_{\mathrm{C}} ; \mathrm{kg}\right.$ day $^{-1}$; mean \pm SE of all individuals in each site/species category) for oaks and pines and (D) total daily leaf-specific transpiration $\left(E_{L} ; \mathrm{kg} \mathrm{m}^{-2}\right.$ leaf area day ${ }^{-1}$; mean \pm SE of all individuals in each site/species category) for oaks and pines. 
performed. Measurements for each year were made in July after the youngest cohort of needles on the Pinus spp. was fully expanded. Six Pinus spp. individuals were measured in each site during each yearly measurement cycle. For oaks in summer 2012, eight $Q$. alba, eight $Q$. prinus, and nine $Q$. velutina individuals were measured, and in 2013, six Q. alba, six Q. prinus, and six $Q$. velutina individuals were measured. Measurements were performed in mid-morning (after any dew had evaporated from leaves) to early afternoon (before significant moisture stress) on sunny days. The average temperature across measurement days was $26.8 \pm 0.7^{\circ} \mathrm{C}$. Humidity levels in the chamber were not controlled unless they became excessive and generally did not differ by more than $10 \%$ from ambient relative humidity measured at each site. Averaged across all curves measured, chamber vapor pressures deficits were about $2.6 \pm 0.09 \mathrm{kPa}$, temperatures were about $28.1 \pm 0.5^{\circ} \mathrm{C}$ and relative humidities were about $42.5 \pm 1.5 \%$. Because crowns could not be accessed directly, stems were cut with a pole pruner, recut under water to remove embolisms, and kept in a container of water located in a sunny understory gap while measurements were being made. Curves were measured within $5 \mathrm{~min}$ of cutting branches from trees in order to minimize the effects of measuring gas exchange on cut branches. Likewise, stomatal conductances in this study were higher than values reported in an earlier study on these oak species when leaves were accessed directly via a canopy lift (Schäfer, 2011). For oaks, the entire leaf chamber was filled with leaf tissue, while for pines, one or two fascicles (3-6 needles) were placed in the leaf chamber for gas exchange measurements. Chamber leaf areas for pines were then adjusted by collecting all leaves inside the chamber, scanning them using a flatbed scanner (Epson V30, Long Beach, CA) with a scaling factor and determining their single-sided area using Image J software (Scion Image, Frederick, MD, USA).

Light response curves were produced by holding $\mathrm{CO}_{2}$ concentrations in the leaf chamber constant at $400 \mathrm{ppm}$ and varying light levels from 1500 to $0 \mu \mathrm{mol}$ photons $\mathrm{m}^{-2} \mathrm{~s}^{-1}$. Light response curves took, on average, $11.6 \pm 1.0 \mathrm{~min}$ to complete with about $86 \pm 6 \mathrm{~s}$ for photosynthetic rates to equilibrate after each light level change. Data were then fitted with non-rectangular hyperbola equations developed by Prioul and Chartier (1977) and curve-fitting routines developed by Lobo et al. (2013). When non-rectangular hyperbola equations did not provide a satisfactory fit, exponential equations were used instead (Lobo et al., 2013). From the fitted equations, parameters describing the light response curves were derived including $A_{\max }$ (maximum photosynthetic assimilation rate), light compensation point (the light required for photosynthetic assimilation to balance respiration), quantum yield (the initial linear increase in photosynthetic assimilation with increasing light) and dark respiration rate (rate of $\mathrm{CO}_{2}$ production in darkness).

To produce $A / C_{\mathrm{i}}$ curves, light levels were held constant at $1500 \mu \mathrm{mol} \mathrm{m} \mathrm{m}^{-2} \mathrm{~s}^{-1}$ and $\mathrm{CO}_{2}$ concentrations in the leaf chamber began at $400 \mathrm{ppm}$, were progressively dropped to $50 \mathrm{ppm}$, returned to $400 \mathrm{ppm}$ and raised by $200 \mathrm{ppm}$ increments until photosynthetic rates saturated. $A / C_{\mathrm{i}}$ curves took, on average, $13.4 \pm 2.1 \mathrm{~min}$ to complete with about $102 \pm 3 \mathrm{~s}$ for photosynthetic rates to equilibrate after each change in $\mathrm{CO}_{2}$ concentration. Leaf-level stomatal conductance $\left(\mathrm{g}_{\mathrm{s}} ; \mathrm{mol} \mathrm{H}_{2} \mathrm{O}\right.$ $\mathrm{m}^{-2} \mathrm{~s}^{-1}$ ) and instantaneous ratios of internal $\mathrm{CO}_{2}$ concentration to ambient $\mathrm{CO}_{2}$ concentration $\left(\mathrm{c}_{\mathrm{i}} / \mathrm{c}_{\mathrm{a}}\right.$ inst. $)$ were estimated from data used to create the light response and $A / C_{\mathrm{i}}$ curves during saturating light levels $\left(1500 \mu \mathrm{mol} \mathrm{m}^{-2} \mathrm{~s}^{-1}\right)$ and ambient $\mathrm{CO}_{2}$ levels $(400 \mathrm{ppm})$ in the leaf chamber. Also, instantaneous water use efficiency (WUE inst.; $\mu \mathrm{mol} \mathrm{CO}_{2} \mathrm{mmol}^{-1} \mathrm{H}_{2} \mathrm{O}$ ) was calculated by dividing corresponding net photosynthetic assimilation $\left(A_{\text {net }} ; \mu \mathrm{mol} \mathrm{CO} \mathrm{CO}^{-2} \mathrm{~s}^{-1}\right)$ by transpiration $(E$; mmol $\left.\mathrm{H}_{2} 0 \mathrm{~m}^{-2} \mathrm{~s}^{-1}\right)$ and instantaneous intrinsic water use efficiency (iWUE inst.; $\mu \mathrm{mol} \mathrm{CO}_{2} \mathrm{~mol}^{-1} \mathrm{H}_{2} \mathrm{O}$ ) was calculated by dividing net assimilation by stomatal conductance at saturating light and ambient $\mathrm{CO}_{2}$.

Data from $A / C_{\mathrm{i}}$ curves were used to calculate maximum Rubisco-limited carboxylation rates $\left(V_{\mathrm{Cmax}}\right)$, maximum electron transport-limited carboxylation rates $\left(J_{\max }\right)$, carboxylation rates limited by triose phosphate utilization (TPU), and daytime respiration rates $\left(R_{\text {day }}\right)$. Non-linear curves based on theory and equations from Farquhar et al. (1980) were fitted to the data after defining the Rubisco-limited, electron transport-limited and triose phosphate utilization-limited portions of the $A / C_{i}$ curves (Sharkey et al., 2007). Curve-fitting routines developed by Sharkey et al. (2007) were used to calculate temperatureadjusted (to $25^{\circ} \mathrm{C}$ ) parameter estimates that minimized the sums of squares error between measured and modeled data, thereby providing estimates of $V_{\mathrm{Cmax} 25}, J_{\max 25}, \mathrm{TPU}_{25}$, and $R_{\text {day25 }}$. Data from $A / C_{\mathrm{i}}$ curves were also used to estimate the Ball-Berry parameter (Leuning, 1990; Collatz et al., 1991) which is the slope $(\mathrm{m})$ of the following equation:

$$
g_{s}=m \times \frac{A \times r h_{s}}{C_{\mathrm{S}}-\Gamma}+g_{o}
$$

where $r h_{s}$ is relative humidity at the leaf surface, $C_{s}$ is $\mathrm{CO}_{2}$ concentration at the leaf surface $\left(\mu \mathrm{mol} \mathrm{mol}^{-1}\right), \Gamma$ is the $\mathrm{CO}_{2}$ compensation point $\left(\mu \mathrm{mol} \mathrm{mol}{ }^{-1}\right)$ of the corresponding $A / C_{i}$ curve and $g_{\mathrm{o}}$ is minimum conductance $\left(\mathrm{mol} \mathrm{H}_{2} \mathrm{O} \mathrm{m}^{-2} \mathrm{~s}^{-1}\right)$. $\Gamma$ was calculated as the $\mathrm{x}$-intercept of a linear regression fitted to the initial points on each $A / C_{\mathrm{i}}$ curve.

\section{Leaf Nutrient and Isotopic Composition}

After photosynthetic measurements were made, leaves were returned to the lab and their areas estimated by scanning them and using image analysis software (see above). Leaves were then dried at $70^{\circ} \mathrm{C}$ for at least 3 days and weighed in order to calculate leaf dry mass per unit area (LMA; $\mathrm{g} \mathrm{m}^{-2}$ ). After weighing, leaves were ground finely using a ball mill, sealed in aluminum capsules and their carbon isotopic ratios $\left(\delta^{13} \mathrm{C}\right)$, carbon and nitrogen concentrations determined (Duke University Stable Isotope facility DEVIL, Durham, NC; UC Davis Stable Isotope facility, Davis, CA). Carbon isotope discrimination $(\Delta ; \%$ ) was calculated from the carbon stable isotope data using the following equation (Farquhar et al., 1989):

$$
\Delta=\left(\frac{\delta^{13} a-\delta^{13} C}{1000+\delta^{13} C}\right) * 1000
$$


where $\delta^{13} \mathrm{a}$ is the isotopic concentration of the source air measured at the SL site by a Picarro G1101-I Isotopic $\mathrm{CO}_{2}$ Analyzer (Picarro Inc. Santa Clara, CA, USA) sampling air at the top of the $19 \mathrm{~m}$ tall canopy tower, $10 \mathrm{~m}$ above ground (at the point of maximum canopy leaf area) and $0.5 \mathrm{~m}$ above ground (data obtained from http://www.nrs.fs.fed.us/data/ climate-tower/). Carbon isotopic ratios of source air averaged $-9.4 \%$ during the first part of the 2011 growing season (MayJuly), $-11.4 \%$ during the first part of the 2012 growing season and $-10.4 \%$ during the first part of the 2013 growing season. Intrinsic water use efficiency (iWUE $\mathrm{iso}_{\text {. }}$ ) and integrated $\mathrm{c}_{\mathrm{i}} / \mathrm{c}_{\mathrm{a}}$ ratios $\left(c_{i} / c_{a}\right.$ iso. $)$ were also estimated from the isotope data as follows (Farquhar et al., 1989):

$$
\begin{aligned}
i W U E_{\text {iso. }} & =\frac{c_{a}}{1.6} \times\left(\frac{27-\Delta}{27-4.4}\right) \\
\frac{c_{i}}{c_{a}} \text { iso. } & =\frac{\Delta-4.4}{27-4.4}
\end{aligned}
$$

where $c_{a}$ is the ambient $\mathrm{CO}_{2}$ concentration $(400 \mathrm{ppm}), 1.6$ is the ratio of water vapor to carbon dioxide diffusivity, $27 \%$ is the discrimination of Rubisco to ${ }^{13} \mathrm{C}$ and $4.4 \%$ is the diffusive discrimination of ${ }^{13} \mathrm{C}$ in air through the stomata.

Leaf $\mathrm{N}$ concentrations were multiplied by LMA to scale $\mathrm{N}$ per unit leaf area $\left(\mathrm{N}_{\text {area }}\right)$. Photosynthetic nitrogen use efficiency (PNUE; $\mu \mathrm{mol} \mathrm{CO}_{2} \mathrm{~g}^{-1} \mathrm{~N} \mathrm{~s}^{-1}$ ) was calculated by dividing net photosynthetic assimilation rates at ambient $\mathrm{CO}_{2}$ and saturating light conditions by the $\mathrm{N}_{\text {area }}$ (Field et al., 1983).

\section{Sap Flow, Canopy Transpiration and Canopy Stomatal Conductance}

In 2011, sap flow rates were measured in seven Q. prinus, five $Q$. velutina, and one $P$. echinata at the SL site and 19 P. rigida at the BTB site. In 2012, sap flow rates were measured in four Q. alba, 11 Q. prinus, 13 Q. velutina, one $P$. echinata, and five $P$. rigida at the SL site, $19 P$. rigida individuals at the BTB site and eight $P$. rigida at the $\mathrm{CB}$ site. In 2013, sap flow rates were measured in four Q. alba, 11 Q. prinus, 13 Q. velutina, one P. echinata, and five $P$. rigida at the SL site and $18 P$. rigida individuals at the CB site. $P$. rigida and $P$. echinata were combined in the analyses as they have similar properties and occasionally, naturally hybridize with one another (Ledig and Little, 1979).

Sap flow rates were measured using Granier-style heat dissipation sensors (Granier, 1987). Sensors consisted of a pair of hypodermic needles with a thermocouple inside each that were radially inserted into the sapwood. One of the sensors was constantly heated and located $0.1 \mathrm{~m}$ above the unheated reference sensor. Quercus spp. received $1 \mathrm{~cm}$ long sensors as they have shallow sapwood and Pinus spp. received $2 \mathrm{~cm}$ long sensors. Pinus spp. individuals larger than $30 \mathrm{~cm}$ diameter breast height (DBH) had an outer (0-2 cm depth) sapwood sensor and an inner sapwood sensor $(2-4 \mathrm{~cm}$ depth) to capture radial patterns in sap flow. Aluminum shields were placed over the sensor pairs to protect against sunflecks and sensors were connected to dataloggers and AM16/32 multiplexers located at each site (Campbell Scientific Inc.) that measured the $\mathrm{mV}$ output of the sensor pairs (proportional to the temperature difference between the heated and reference sensor) every $30 \mathrm{~s}$ and averaged data every $30 \mathrm{~min}$. An empirical equation was used to convert $\mathrm{mV}$ values to sap flow rates $\left(J_{S} ; \mathrm{kg} \mathrm{m}^{-2} \mathrm{~s}^{-1}\right)$ as follows (Granier, 1987):

$$
J_{s}=0.119 \times\left[\frac{\Delta T_{\max }}{\Delta T}-1\right]^{1.23}
$$

where $\Delta T_{\max }$ is the temperature difference between sensors when no water is flowing and $\Delta T$ is the temperature difference when sap flow is occurring. To determine zero flow conditions for $\Delta \mathrm{T}_{\max }$, data were chosen when $\mathrm{VPD}<0.05 \mathrm{kPa}$ over a $2 \mathrm{~h}$ period and $\Delta \mathrm{T}_{\max }$ values were stable over a $2 \mathrm{~h}$ period (Oishi et al., 2008). Additionally, because Quercus spp. are ring-porous and sap flow measured with heat dissipation sensors tends to be underestimated (Taneda and Sperry, 2008; Bush et al., 2010; Hultine et al., 2010), an additional correction was applied to the sap flow data as described in Renninger and Schäfer (2012).

Individual whole-canopy transpiration rates $\left(\mathrm{E}_{\mathrm{C}} ; \mathrm{kg} \mathrm{day}^{-1}\right)$ were calculated by multiplying half-hourly sap flow rates by the sapwood area $\left(A_{\mathrm{S}}, \mathrm{m}^{2}\right)$ of the individual (Figure 2C). For oaks, relationships between $\mathrm{DBH}$ and $\mathrm{A}_{\mathrm{S}}$ were made by coring selected individuals and determining sapwood depth via a color change between sapwood and heartwood (Phillips et al., 2003). For all measured Quercus spp., the following sigmoidal equation $\left(r^{2}=\right.$ 0.88 ) was used to calculate As:

$$
A_{S}\left(m^{2}\right)=\frac{0.0188}{1-e^{-\left(\frac{D B H(c m)-20.97}{4.791}\right)}}
$$

An equation for calculating As from DBH for Pinus spp. has been previously reported in Renninger et al. (2013) and was used in this study as well. Leaf-specific transpiration rates $\left(E_{\mathrm{L}} ; \mathrm{kg} \mathrm{m}^{-2}\right.$ leaf area day $^{-1}$ ) were calculated by dividing sap flow per unit $A_{S}$ by the leaf area of each individual (Figure 2D). For oaks, leaf areas were estimated in 2012 using an LAI2000 leaf area meter (LICOR Biosciences Inc.). Specific methodologies are described in Renninger et al. (2014). Briefly, light transmittance was measured at dawn at four locations under each tree and compared with a sensor measuring clear sky conditions to estimate leaf density (leaf area/canopy volume). Canopy profiles were measured on two planes for each tree in order to calculate canopy volume. Trees were sufficiently spaced so that canopies did not overlap with one another. Leaf areas in 2011 and 2013 were calculated from corresponding $A_{S}$ assuming that leaf area to sapwood area ratios remained constant throughout the study period (Rogers and Hinckley, 1979). For pines, leaf areas were calculated using an allometric equation reported in Whittaker and Woodwell (1968) that was developed for Pinus rigida growing on sandy soils in Long Island, NY, USA. Because this equation calculates all-sided leaf areas for Pinus spp., a single-sided leaf area was calculated by dividing all-sided leaf areas by $\pi$ (Vose et al., 1994).

Mean canopy stomatal conductance to water vapor $\left(G_{S} ; \mathrm{m}\right.$ $\mathrm{s}^{-1}$ ) was also estimated from the half-hourly $E_{\mathrm{L}}$ data as follows (Köstner et al., 1992; Ewers et al., 2001):

$$
G_{s}=\frac{K_{G} * E_{L}}{V P D}
$$


where $K_{\mathrm{G}}$ is a conductance coefficient $[115.8+0.4236$ *air temperature in ${ }^{\circ} \mathrm{C}$; Phillips and Oren (1998)]. In order to convert mean canopy stomatal conductance in $\mathrm{m} \mathrm{s}^{-1}$ to mol $\mathrm{H}_{2} \mathrm{O} \mathrm{m} \mathrm{m}^{-2} \mathrm{~s}^{-1}, G_{\mathrm{S}}$ was divided by the density of water vapor $\left(\mathrm{m}^{3} / \mathrm{mol}, 0.0224 * \frac{\text { air temp. }(K)}{273}\right)$. These equations require that boundary layer conductance is high, leaf temperature and air temperature are similar, VPD is constant throughout the canopy and there is negligible use of stored bole water. Forests in the New Jersey Pinelands are relatively open and individual tree crowns have low leaf area densities, therefore individual leaves are assumed to be coupled with the surrounding atmosphere and air within the canopy is assumed to be well-mixed. For oaks, sapwood volumes are relatively small, and therefore, stored bole water use is negligible (Renninger et al., 2014). For pines, lag analysis between bole sap flow and VPD showed that stored bole water did not contribute significantly to transpiration (Phillips et al., 1997). Once half-hourly $G_{S}$ was calculated, average daytime values were obtained by averaging all halfhourly $G_{S}$ corresponding to half-hourly VPD above $0.5 \mathrm{kPa}$ (Ewers et al., 2001). For each individual, average daytime $\mathrm{G}_{S}$ values were plotted vs. the natural log of VPD and linear regressions fitted to these data. The negative slope of this relationship (representing stomatal sensitivity to $\mathrm{VPD} ; \delta \mathrm{G}_{\mathrm{S}} / \delta$ $\ln V P D$ ) and the $y$ intercept (representing reference $\mathrm{G}_{S}$ at VPD $=1 \mathrm{kPa} ; \mathrm{G}_{\text {Sref; }}$ Oren et al., 1999) were recorded. The ratio of stomatal sensitivity to VPD and $\mathrm{G}_{\text {Sref }}$ was then calculated which represents a stomatal sensitivity normalized by reference stomatal conductance ("stomatal sensitivity ratio").

\section{Data Analysis and Statistics}

Leaf-level gas exchange and composition parameters were compared between oaks and pines using linear mixed effects models in R version 3.1.2 [lme function; Pinheiro et al. (2014)] with "tree within site" included as a random effect in each model. Post-hoc tests were also performed to compare parameters across oak species and pines across the three sites using the general linear hypotheses test [glht function in the multcomp package; Hothorn et al. (2008)] with Tukey contrasts in R (Tables S1, S2). Regressions were plotted and estimates of $r^{2}$ and slope $p$ values were performed in Sigmaplot (SPSS Inc., Chicago, IL, USA). Analysis of covariance (ANCOVA) was performed in R using the aov function to compare slopes of linear regression relationships between oaks and pines. In order to determine if stomata responded differently to changes in VPD across a soil moisture or energy availability (represented by PPFD) gradient, mean daytime $\mathrm{G}_{S}$ data were sorted by either relative soil moisture content or daily integrated PPFD (mol m$\left.{ }^{-2} \mathrm{~d}^{-1}\right)$ and grouped under similar daily soil moisture or light conditions. Relative soil moisture content was calculated as soil moisture content divided by the highest soil moisture content measured in each study site (assumed to be field capacity). In each soil moisture or daytime PPFD category, mean daytime $\mathrm{G}_{S}$ was plotted vs. natural logtransformed mean daytime VPD and linear regressions fitted to the data. The slope of these regression equations $\left(\delta \mathrm{G}_{S} / \delta \ln \mathrm{VPD}\right)$ represents canopy stomatal sensitivity to VPD (Oren et al., 1999) and these slope parameters were plotted across a soil moisture or daytime PPFD gradient to determine how stomatal sensitivity to VPD was affected by soil moisture deficits and energy availability.

\section{Results}

\section{Between Year and between Site Environmental Variation}

Daytime temperatures were, on average, $25.0 \pm 0.3^{\circ} \mathrm{C}$ in 2011 , $24.9 \pm 0.4^{\circ} \mathrm{C}$ in 2012 and $24.4 \pm 0.3^{\circ} \mathrm{C}$ in 2013 during each growing season (June-Aug.) and average daytime VPD was $1.27 \pm 0.05 \mathrm{kPa}$ in $2011,1.28 \pm 0.06 \mathrm{kPa}$ in 2012 and $0.98 \pm$ $0.04 \mathrm{kPa}$ in 2013 during each summer growing season (Figure 2). In 2011, the sites received about $1290 \mathrm{~mm}$ of throughfall and soil moisture in the upper $30 \mathrm{~cm}$ during the summer averaged about $0.06 \pm 0.002 \mathrm{~m}^{3} \mathrm{~m}^{-3}$ at the SL site. In 2012, the sites received about $1050 \mathrm{~mm}$ of throughfall and soil moisture averaged about $0.06 \pm 0.001 \mathrm{~m}^{3} \mathrm{~m}^{-3}$ at the SL site. In 2013, the sites received about $1210 \mathrm{~mm}$ of throughfall and soil moisture averaged about $0.07 \pm 0.002 \mathrm{~m}^{3} \mathrm{~m}^{-3}$ at the SL site (Figure 2). For maximum daytime photosynthetic photon flux density (PPFD), 2011 and 2012 had similar averages over the summer growing season with $1680 \pm 33 \mu \mathrm{mol} \mathrm{m} \mathrm{m}^{-2} \mathrm{~s}^{-1}$ and $1681 \pm 36 \mu \mathrm{mol} \mathrm{m} \mathrm{m}^{-2} \mathrm{~s}^{-1}$ respectively while 2013 was slightly lower with $1671 \pm 39 \mu \mathrm{mol}$ $\mathrm{m}^{-2} \mathrm{~s}^{-1}$. Between sites, daily soil moisture in the upper $30 \mathrm{~cm}$ during the 2012 summer growing season averaged about $0.06 \pm$ $0.002 \mathrm{~m}^{3} \mathrm{~m}^{-3}$ at the SL site, $0.08 \pm 0.002 \mathrm{~m}^{3} \mathrm{~m}^{-3}$ at the BTB site and $0.10 \pm 0.003 \mathrm{~m}^{3} \mathrm{~m}^{-3}$ at the $\mathrm{CB}$ site. Therefore, 2011 and 2012 were similar in terms of environmental conditions with 2013 exhibiting less atmospheric and soil moisture deficits compared with the prior years. Between sites, soil moisture in the upper layers was generally higher with increasing proximity to the ocean while depth to the groundwater also increased in the sites from west to east (Figure 1).

\section{Leaf-Level Gas Exchange}

All photosynthetic parameters describing the light response and $A / C_{\mathrm{i}}$ curves were statistically similar (across sites and species) between oak and pine foliage (Table 1). Across oak species, $Q$. velutina had statistically higher $A_{\max }$ rates than $Q$. alba and Q. prinus as well as higher $\mathrm{V}_{\mathrm{Cmax}}, \mathrm{J}_{\max }$, TPU and daytime respiration rates compared to the other oak species (Table S1). Across sites, parameters estimated from light response and $A / C_{\mathrm{i}}$ curves were similar for pines except daytime respiration rates which were significantly higher in the SL site than the other two sites (Table S2). Oak foliage had significantly higher transpiration rates $(\mathrm{E})$, stomatal conductances $\left(\mathrm{g}_{\mathrm{s}}\right)$ and $\mathrm{c}_{\mathrm{i}} / \mathrm{c}_{\mathrm{a}}$ inst ratios based on gas exchange compared with pine foliage, and therefore had significantly lower water use efficiency $\left(W_{U^{\prime}} E_{\text {int. }}\right)$ and intrinsic water use efficiency (iWUE inst. $_{\text {; }}$ Table 1). Across oak species, $Q$. velutina tended to have the largest transpiration, stomatal conductance and $\mathrm{c}_{\mathrm{i}} / \mathrm{c}_{\mathrm{a}}$ inst ratios, but species exhibited similar WUE (although Q. alba had a significantly higher intrinsic iWUE $_{\text {inst; }}$ Table S1). Across sites, pines at the SL site had significantly lower transpiration rates and $\mathrm{ci} / \mathrm{c}_{\mathrm{a}}$ inst ratios compared to the other two sites, but had the highest WUE

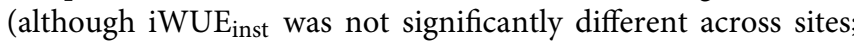
Table S2). For the physiological components that comprise 
TABLE 1 | Means and standard error (in parentheses) of leaf-level gas exchange, isotope and nutrient parameters across all measured oak and pine individuals.

\begin{tabular}{|c|c|c|c|}
\hline & Quercus spp. & Pinus spp. & $P$-value \\
\hline 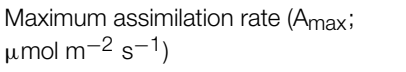 & $16.2(0.5)$ & $16.4(0.8)$ & 0.99 \\
\hline Quantum yield $\left(\mu \mathrm{mol} \mu \mathrm{mol}^{-1}\right)$ & $0.049(0.002)$ & $0.047(0.003)$ & 0.92 \\
\hline $\begin{array}{l}\text { Light compensation pt. }\left(\mu \mathrm{mol} \mathrm{m}{ }^{-2}\right. \\
\left.\mathrm{s}^{-1}\right)\end{array}$ & $21.7(2.3)$ & $21.3(2.8)$ & 0.69 \\
\hline Dark respiration rate $\left(\mu \mathrm{mol} \mathrm{m} \mathrm{m}^{-2} \mathrm{~s}^{-1}\right)$ & $0.97(0.10)$ & $0.92(0.13)$ & 0.63 \\
\hline$V_{C \max , 25}\left(\mu \mathrm{mol} \mathrm{m} \mathrm{m}^{-2} \mathrm{~s}^{-1}\right)^{\mathrm{a}}$ & $85.4(5.8)$ & $83.1(4.9)$ & 0.82 \\
\hline$J_{\max , 25}\left(\mu \mathrm{mol} \mathrm{m} \mathrm{m}^{-2} \mathrm{~s}^{-1}\right)^{\mathrm{b}}$ & $100.5(9.4)$ & $95.1(7.1)$ & 0.78 \\
\hline $\operatorname{TPU}_{, 25}\left(\mu \mathrm{mol} \mathrm{m} \mathrm{m}^{-2} \mathrm{~s}^{-1}\right)^{\mathrm{C}}$ & $6.8(0.6)$ & $6.9(0.5)$ & 0.48 \\
\hline $\begin{array}{l}\text { Daytime respiration rate }\left(\mu \mathrm{mol} \mathrm{m}^{-2}\right. \\
\left.\mathrm{s}^{-1}\right)\end{array}$ & $3.8(0.7)$ & $4.4(0.5)$ & 0.09 \\
\hline Transpiration (E; mmol m${ }^{-2} \mathrm{~s}^{-1}$ ) & $5.16(0.31)$ & $4.70(0.28)$ & 0.02 \\
\hline $\begin{array}{l}\text { Stomatal conductance }\left(\mathrm{g}_{\mathrm{s}} ; \mathrm{mol} \mathrm{m}^{-2}\right. \\
\left.\mathrm{s}^{-1}\right)\end{array}$ & $0.26(0.02)$ & $0.18(0.01)$ & 0.001 \\
\hline $\mathrm{c}_{\mathrm{i}} / \mathrm{c}_{\mathrm{a}}$ inst. ${ }^{\mathrm{d}}$ & $0.70(0.01)$ & $0.62(0.012)$ & $<0.001$ \\
\hline WUE $E_{\text {inst. }}\left(A / E ; \mu \mathrm{mol} \mathrm{mmol}^{-1}\right)^{\mathrm{e}}$ & $3.49(0.20)$ & $3.59(0.30)$ & 0.03 \\
\hline iWUE $_{\text {inst }} \cdot\left(A / g_{s} ; \mu \mathrm{mol} \mathrm{mol}{ }^{-1}\right)^{f}$ & $63.2(2.3)$ & $92.4(4.7)$ & 0.02 \\
\hline Ball-Berry parameter (m) & $7.8(0.8)$ & $5.4(1.3)$ & 0.08 \\
\hline$\delta^{13} \mathrm{C}(\% 0)^{9}$ & $-29.7(0.2)$ & $-30.3(0.2)$ & 0.18 \\
\hline$\Delta(\%))^{h}$ & $19.1(0.2)$ & $20.4(0.3)$ & 0.17 \\
\hline $\mathrm{C}_{\mathrm{i}} / \mathrm{C}_{\mathrm{a}}$ iso. ${ }^{\mathrm{i}}$ & $0.65(0.008)$ & $0.71(0.01)$ & 0.17 \\
\hline $\mathrm{iWUE}_{\text {iso. }}\left(\mu \mathrm{mol} \mathrm{mol}{ }^{-1}\right)^{\mathrm{j}}$ & $87.8(2.0)$ & $73.5(3.1)$ & 0.17 \\
\hline Leaf mass per area (LMA; $\left.\mathrm{g} \mathrm{m}^{-2}\right)$ & $100.4(3.7)$ & $240.7(7.3)$ & $<0.001$ \\
\hline Leaf nitrogen concentration ( $\mathrm{N}$; \%) & $2.16(0.04)$ & $1.03(0.03)$ & $<0.001$ \\
\hline Leaf carbon concentration (C; \%) & $48.4(0.5)$ & $48.2(0.4)$ & 0.75 \\
\hline Leaf $\mathrm{C} / \mathrm{N}$ ratio & $22.6(0.3)$ & $47.6(1.2)$ & $<0.001$ \\
\hline $\begin{array}{l}\text { Nitrogen per unit leaf area ( } N \text { area; } g \\
m^{-2} \text { ) }\end{array}$ & $2.17(0.07)$ & $2.47(0.09)$ & 0.006 \\
\hline PNUE $\left(\mu \mathrm{mol} \mathrm{g} \mathrm{g}^{-1} \mathrm{~s}^{-1}\right)^{\mathrm{k}}$ & $7.07(0.19)$ & $6.16(0.40)$ & 0.01 \\
\hline
\end{tabular}

Bold P-values denote significance at $\alpha<0.05$.

${ }^{a}$ Rubisco-limited carboxylation rate at $25^{\circ} \mathrm{C}$.

${ }^{b}$ Electron transport-limited carboxylation rate at $25^{\circ} \mathrm{C}$.

${ }^{c}$ Triose phosphate utilization-limited carboxylation rate at $25^{\circ} \mathrm{C}$.

${ }^{d}$ Instantaneous ratio of $\left[\mathrm{CO}_{2}\right]_{\text {inside leaf }}$ to $\left[\mathrm{CO}_{2}\right]_{\text {ambient air }}$.

eInstantenous water-use efficiency.

${ }^{f}$ Instantenous intrinsic water-use efficiency.

${ }^{g}$ Leaf isotopic ratio.

${ }^{h}$ Leaf isotopic discrimination.

${ }^{i}$ Ratio of $\left[\mathrm{CO}_{2}\right]_{\text {inside leaf }}$ to $\left[\mathrm{CO}_{2}\right]_{\text {ambient }}$ air based on carbon isotope discrimination.

${ }^{i}$ Intrinsic water-use efficiency based on carbon isotope discrimination.

kPhotosynthetic nitrogen-use efficiency.

instantaneous intrinsic water use efficiency, both oaks and pines displayed similar negative slope terms $(P=0.25)$ in the relationship between net photosynthetic assimilation rates $\left(\mathrm{A}_{\text {net }}\right)$ and $\mathrm{iWUE}_{\text {inst. }}$ (Figure 3A; $r^{2}=0.13$ and 0.19 for oaks and pines respectively) although pines displayed a wider range of $A_{\text {net }}$ values. Likewise, both oaks and pines had a statistically similar $(P=0.46)$ negative relationship between stomatal conductance and iWUE $_{\text {inst. }}$ (Figure 3B; $r^{2}=$ 0.79 and 0.54 for oaks and pines respectively) with pines having lower stomatal conductances but higher LMA than oaks (Figure 3C). The Ball-Berry parameter, which describes the rate of change in leaf-level stomatal conductance with assimilation rate, leaf surface $\mathrm{CO}_{2}$ concentration and leaf surface humidity was also statistically similar between oak and pine foliage (Table 1).

\section{Leaf Isotope and Nutrient Content}

Although pines had significantly greater water use efficiencies based on instantaneous leaf gas exchange, oaks, and pines were not significantly different in terms of intrinsic WUE based on carbon isotope data (iWUE $\mathrm{iso}_{\text {iso; }}$ Table 1). Across species, oaks

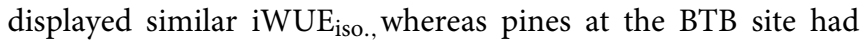
significantly lower $\mathrm{iWUE}_{\mathrm{iso}}$, than pines at the SL or $\mathrm{CB}$ sites (Tables S1, S2). Pine needles exhibited over 2.5 times higher LMA compared with oak leaves, however oak leaves had about double the $\mathrm{N}$ concentrations and half the $\mathrm{C} / \mathrm{N}$ ratios compared with pine needles (Table 1). Across oak species, Q. alba had significantly lower LMA and $\mathrm{C} / \mathrm{N}$ ratios but higher leaf $\mathrm{N}$ concentration compared with Q. prinus and Q. velutina (Table S1). LMA did not differ between pines growing in different sites, but pines at the SL site had significantly higher leaf $\mathrm{N}$ concentrations and lower $\mathrm{C} / \mathrm{N}$ ratios compared with pines growing at the $\mathrm{BTB}$ and $\mathrm{CB}$ sites (Table S2). When $\mathrm{N}$ concentrations were expressed per unit leaf area, pines had significantly higher $\mathrm{N}_{\text {area }}$ and significantly lower photosynthetic nitrogen use efficiencies (PNUE) compared with oaks (Table 1). Across oak species, Q. alba had significantly lower $\mathrm{N}_{\text {area }}$ but all species had similar PNUE (Table S1), while pines across sites had similar $\mathrm{N}_{\text {area }}$ and PNUE (Table S2). In terms of the physiological components that comprise PNUE, both oaks and pines displayed a statistically similar $(P=0.13)$ positive relationship between $A_{\max }$ and PNUE (Figure 4A; $r^{2}=0.58$ ), no relationship between leaf $N$ concentration and PNUE (Figure $4 \mathbf{B}$; $P=0.20)$, statistically similar $(P=0.98)$ negative slope terms in the relationship between LMA and PNUE (Figure 4C; $r^{2}=$ 0.30 and 0.12 for oaks and pines respectively), and a statistically similar $(P=0.31)$ negative relationship between $\mathrm{N}_{\text {area }}$ and PNUE (Figure 4D; $r^{2}=0.38$ ). Pines exhibited a significant negative relationship between PNUE and iWUE inst. $\left(r^{2}=0.21\right.$, $P=0.006)$, while for oaks, the relationship was not significant (Figure 5).

\section{Transpiration and Canopy Stomatal Conductance}

Individual tree-level transpiration rates $\left(\mathrm{E}_{C}\right)$ were, on average, about three times larger in pines compared to oaks during the growing season (Figure 2C; Table 2). Across sites, individual pine water use during the growing season was highest at the SL site with an average of $5200 \mathrm{~kg}$ tree $^{-1}$ followed by pines at the CB site with $2700 \mathrm{~kg}$ tree ${ }^{-1}$ and pines at the BTB site with $2100 \mathrm{~kg}$ tree $^{-1}$. Across oak species, Q. prinus had the highest individual tree water use with, on average, about $1300 \mathrm{~kg} \mathrm{tree}^{-1}$, followed by $Q$. velutina with about $1100 \mathrm{~kg}^{\text {tree }}{ }^{-1}$ and $Q$. alba with about $880 \mathrm{~kg}$ tree ${ }^{-1}$. Therefore, at the pine-dominated stands (BTB and $\mathrm{CB}$ ), individual tree water use in pines was about twice that of oaks but, at the oak-dominated (SL) site, more than four times greater in pines than oaks. On a yearly basis, pines transpired, on average, another $1200 \mathrm{~kg} \mathrm{tree}^{-1}$ during the oak leaf-off period which is similar to the total yearly transpiration for oaks (Table 2). Because total growing season leaf areas for 


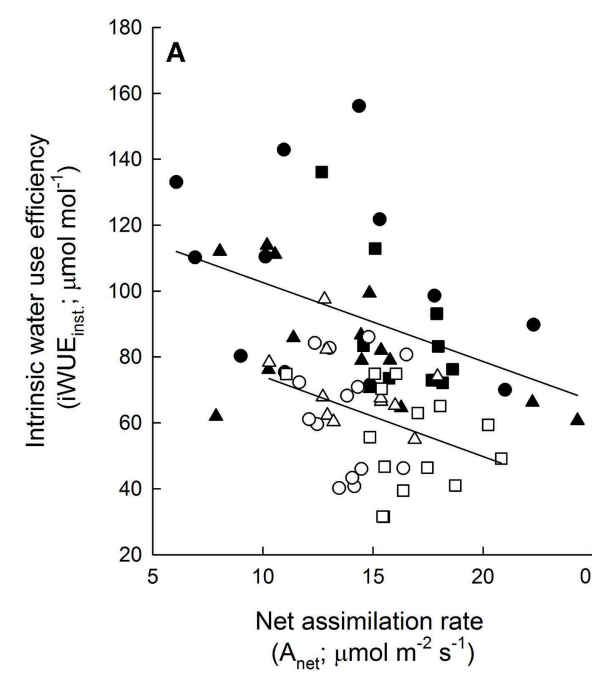

FIGURE 3 | Instantaneous intrinsic water use efficiency (iWUE inst. $_{\text {; }}$ $\mu \mathrm{mol} \mathrm{CO} \mathrm{mol}^{-1} \mathrm{H}_{2} \mathrm{O}$ ) vs. (A) net photosynthetic assimilation rate $\left(A_{\text {net }} ; \mu \mathrm{mol} \mathrm{m} \mathrm{m}^{-2} \mathrm{~s}^{-1}\right.$ ) for oaks $\left(y=-2.4 \mathrm{x}+98.5 ; r^{2}=0.13\right.$ ) and pines $\left(y=-2.4 x+126.6 ; r^{2}=0.19\right)$, (B) stomatal conductance $\left(g_{\mathrm{s}}\right.$; mol $\left.\mathrm{H}_{2} \mathrm{O} \mathrm{m}^{-2} \mathrm{~s}^{-1}\right)$ for oaks $\left(y=-143 x+100.3 ; r^{2}=0.79\right)$ and

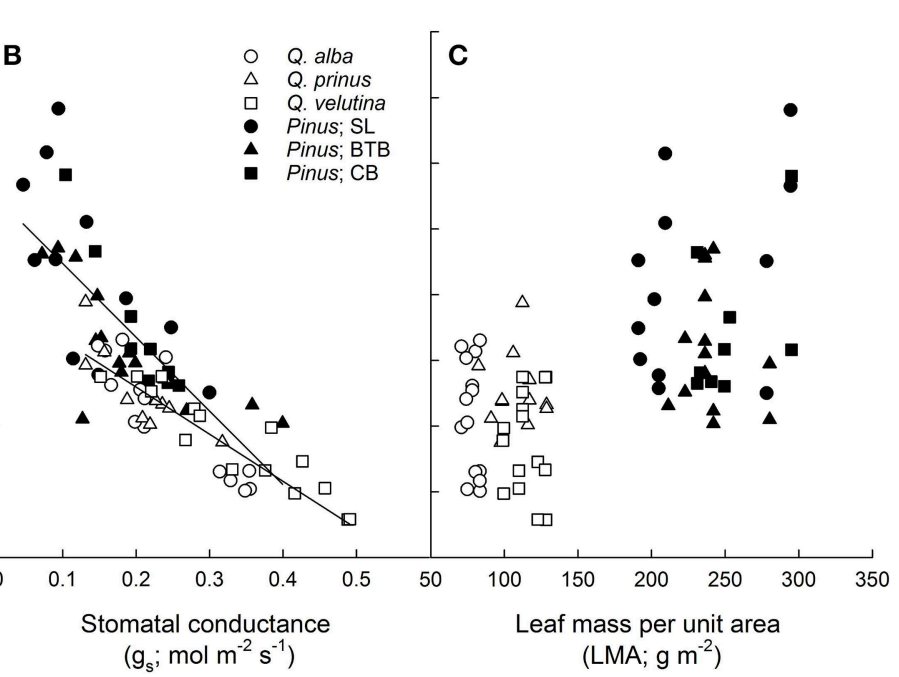

pines $\left(y=-224 x+131.6 ; r^{2}=0.54\right)$, and (C) leaf mass per unit area (LMA; $\mathbf{g ~ m}^{-2}$ ) for oaks and pines. Points represent average across $A / C_{i}$ and light response curves for each individual during each measurement period. Solid lines represent significant relationships (slope $P<0.05)$.

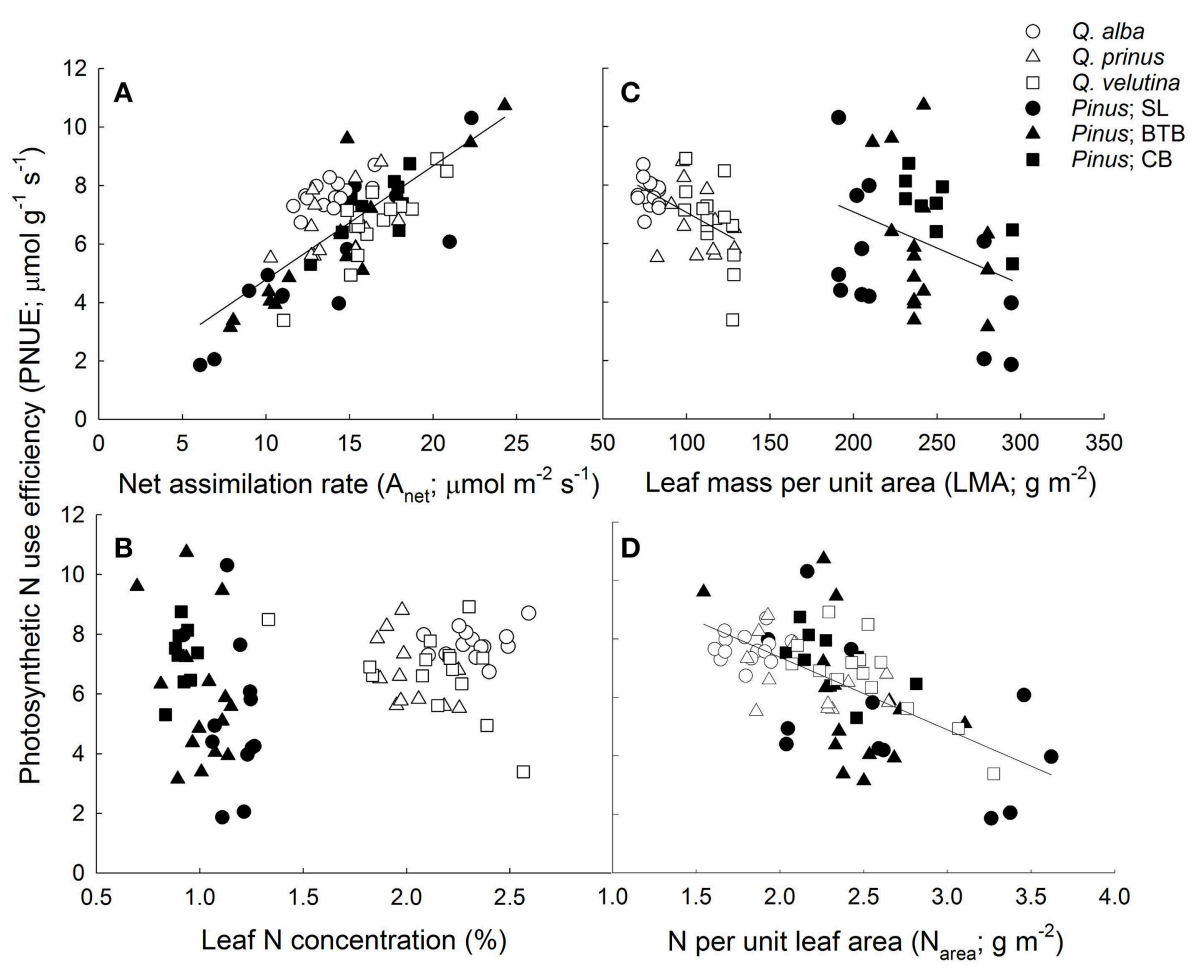

FIGURE 4 | Photosynthetic nitrogen use efficiency (PNUE; $\mu \mathrm{mol}$ $\mathrm{CO}_{2} \mathrm{~g}^{-1} \mathrm{~N} \mathrm{~s}^{-1}$ ) vs. (A) net photosynthetic assimilation rate $\left(A_{\text {net }} ; \mu \mathrm{mol} \mathrm{CO}_{2} \mathrm{~m}^{-2} \mathrm{~s}^{-1} ; y=0.39 \mathrm{x}+0.89 ; r^{2}=0.58\right)$ for oaks and pines, (B) leaf $\mathrm{N}$ concentration (\%), (C) leaf mass per unit area (LMA; $\mathrm{g} \mathrm{m}^{-2}$ ) for oaks $\left(y=-0.032 x+10.2 ; r^{2}=0.3\right)$ and pines $\left(y=-0.027 x+12.0 ; r^{2}=0.12\right)$, and (D) $N$ per unit area $\left(\mathrm{N}_{\text {area }} ; \mathrm{g} \mathrm{N} \mathrm{m}^{-2}\right)$ for oaks and pines $(y=-2.48 \mathrm{x}+12.3$; $r^{2}=\mathbf{0 . 3 8}$ ). Points represent average across $A / C_{j}$ and light response curves for each individual during each measurement period. Solid lines represent significant relationships (slope $P<0.05$ ). 


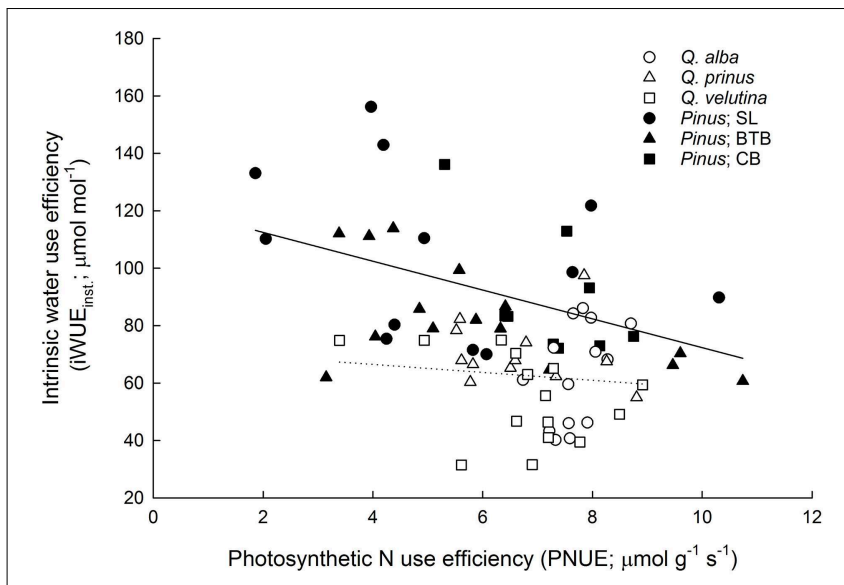

FIGURE 5 | Photosynthetic nitrogen use efficiency (PNUE; $\mu \mathrm{mol} \mathrm{CO}_{2}$ $\mathrm{g}^{-1} \mathrm{~N} \mathrm{~s}^{-1}$ ) vs. instantaneous intrinsic water use efficiency (iWUE $E_{\text {inst. }}$; $\mu \mathrm{mol} \mathrm{CO} \mathbf{~ m o l}^{-1} \mathrm{H}_{2} \mathrm{O}$ ) for oaks and pines. Pines exhibited a significant negative relationship (solid line; $y=-5.02 x+122.5 ; r^{2}=0.21$ ) between PNUE and $i W U E_{\text {inst. }}$, while the slope of the relationship for oak was not statistically different from zero (dotted line; $P=0.54$ ). Points represent average across $A / C_{i}$ and light response curves for each individual during each measurement period. Solid lines represent significant relationships (slope $P<0.05$ ); dotted lines represent non-significant relationships (slope $P>0.05$ ).

individuals are, on average, over five times higher for pines compared to oaks, average canopy leaf-specific transpiration rates $\left(\mathrm{E}_{\mathrm{L}}\right)$ were over 2.5 times greater for oaks compared to pines (Figure 2D; Table 2). Across sites, pines had similar $\mathrm{E}_{\mathrm{L}}$ at the SL and CB sites averaging $0.58 \pm 0.05 \mathrm{~kg} \mathrm{~m}^{-2} \mathrm{~d}^{-1}$ across years, but lower $\mathrm{E}_{\mathrm{L}}$ at the BTB site $\left(0.35 \pm 0.03 \mathrm{~kg} \mathrm{~m}^{-2} \mathrm{~d}^{-1}\right)$. For oaks at the SL site, $Q$. velutina had the highest $\mathrm{E}_{\mathrm{L}}$ averaging $1.78 \pm$ $0.3 \mathrm{~kg} \mathrm{~m}^{-2} \mathrm{~d}^{-1}$ across years, followed by $Q$. prinus $(1.23 \pm 0.1 \mathrm{~kg}$ $\left.\mathrm{m}^{-2} \mathrm{~d}^{-1}\right)$ and $Q$. alba $\left(0.6 \pm 0.06 \mathrm{~kg} \mathrm{~m}^{-2} \mathrm{~d}^{-1}\right)$. Across sites for pines, $E_{L}$ was highest in $2013\left(0.6 \pm 0.1 \mathrm{~kg} \mathrm{~m}^{-2} \mathrm{~d}^{-1}\right)$ followed by $2011\left(0.52 \pm 0.07 \mathrm{~kg} \mathrm{~m}^{-2} \mathrm{~d}^{-1}\right)$ and $2012\left(0.4 \pm 0.07 \mathrm{~kg} \mathrm{~m}^{-2} \mathrm{~d}^{-1}\right.$; Figure 2). The opposite pattern was found for oaks across species with 2012 having the highest $\mathrm{E}_{\mathrm{L}}\left(1.4 \pm 0.5 \mathrm{~kg} \mathrm{~m}^{-2} \mathrm{~d}^{-1}\right)$, followed by $2011\left(1.2 \pm 0.4 \mathrm{~kg} \mathrm{~m}^{-2} \mathrm{~d}^{-1}\right)$ and $2013\left(0.99 \pm 0.2 \mathrm{~kg} \mathrm{~m}^{-2}\right.$ $\mathrm{d}^{-1}$; Figure 2). Similar to $E_{\mathrm{L}}$, mean daytime canopy stomatal conductance ( $\mathrm{G}_{\mathrm{s}} ; \mathrm{mol} \mathrm{m}^{-2} \mathrm{~s}^{-1}$ ) measured when mean daytime $\mathrm{VPD}=1 \mathrm{kPa}$ was almost twice as high in oaks compared to pines (Table 2). Across sites, pines at the BTB site had the highest $\mathrm{G}_{S}$ at $\mathrm{VPD}=1 \mathrm{kPa}$ averaging $0.09 \pm 0.003 \mathrm{~mol} \mathrm{~m}^{-2} \mathrm{~s}^{-1}$ across years, followed by pines at the SL site $\left(0.08 \pm 0.006 \mathrm{~mol} \mathrm{~m}^{-2} \mathrm{~s}^{-1}\right)$ and pines at the $\mathrm{CB}$ site $\left(0.06 \pm 0.005 \mathrm{~mol} \mathrm{~m}^{-2} \mathrm{~s}^{-1}\right)$. For oak species, $Q$ velutina had the highest $\mathrm{G}_{\mathrm{S}}$ at $\mathrm{VPD}=1 \mathrm{kPa}$ averaging $0.20 \pm$ $0.009 \mathrm{~mol} \mathrm{~m}^{-2} \mathrm{~s}^{-1}$ across years, followed by $Q$. prinus $(0.15 \pm$ $\left.0.007 \mathrm{~mol} \mathrm{~m}^{-2} \mathrm{~s}^{-1}\right)$ and Q. alba $\left(0.07 \pm 0.003 \mathrm{~mol} \mathrm{~m}^{-2} \mathrm{~s}^{-1}\right)$.

Both oaks and pines exhibited significant negative relationships between canopy stomatal conductance and $\ln V P D$, with oaks having a slope term $\left(\delta G_{S} / \delta \ln V P D\right)$ that was significantly more negative $(\mathrm{P}<0.001)$ compared to pines (Figures 6A,B). However, when stomatal sensitivity ratios, which represent stomatal sensitivity to $\mathrm{VPD}\left(\delta \mathrm{G}_{\mathrm{S}} / \delta \ln \mathrm{VPD}\right)$ normalized by $\mathrm{G}_{\mathrm{Sref}}$, were calculated for each individual, oaks
TABLE 2 | Means and standard error (in parentheses) of morphological and canopy-level water use properties for individual oaks and pines averaged across all years and study sites.

\begin{tabular}{|c|c|c|c|}
\hline & Quercus spp. & Pinus spp. & $P$-value \\
\hline Diameter at breast height (DBH; cm) & $19.5(0.9)$ & $24.1(1.3)$ & 0.006 \\
\hline Crown area $\left(\mathrm{m}^{2}\right)$ & $7.9(1.3)$ & $10.7(1.3)$ & 0.15 \\
\hline Sapwood area $\left(\mathrm{m}^{2}\right)$ & $0.0086(0.0008)$ & $0.028(0.003)$ & $<0.001$ \\
\hline Leaf area $\left(\mathrm{m}^{2}\right)$ & $8.3(1.1)$ & $45.9(5.1)$ & $<0.001$ \\
\hline $\begin{array}{l}\text { Growing season water use }\left(E_{C} ; \mathrm{kg}\right. \\
\left.\text { tree } e^{-1}\right)\end{array}$ & $1200(130)$ & $3600(660)$ & $<0.001$ \\
\hline $\begin{array}{l}\text { Total yearly water use }\left(\mathrm{E}_{\mathrm{C}} ; \mathrm{kg}_{\mathrm{kree}} \mathrm{tr}^{-1}\right. \\
\left.\text { year-1 }^{-1}\right)\end{array}$ & $1200(130)$ & $4800(900)$ & $<0.001$ \\
\hline $\begin{array}{l}\text { Avg. daily leaf-specific transpiration } \\
\left(E_{L} ; \mathrm{kg} \mathrm{m}^{-2} \mathrm{day}^{-1}\right)\end{array}$ & $1.36(0.14)$ & $0.49(0.03)$ & $<0.001$ \\
\hline $\begin{array}{l}\text { Avg. daytime canopy stomatal } \\
\text { conductance }\left(G_{S} ; \mathrm{mol} \mathrm{m}^{-2} \mathrm{~s}^{-1}\right)^{\star}\end{array}$ & $0.15(0.006)$ & $0.08(0.002)$ & $<0.001$ \\
\hline
\end{tabular}

Bold $P$-values denote significance at $\alpha<0.05$. *at average daytime vapor pressure deficit $(N P D)=1 \mathrm{kPa}$

had a significantly $(P=0.003)$ lower ratio $(0.57 \pm 0.02)$ compared with pines $(0.64 \pm 0.04)$. For oaks, stomatal sensitivity ratios were not significantly different $(P=0.3)$ across species and $Q$. alba had the highest ratio $(0.63 \pm 0.04)$ followed by $Q$. velutina $(0.55 \pm 0.03)$ and $Q$. prinus $(0.53 \pm 0.03)$. However stomatal sensitivity ratios did differ significantly $(P<0.001)$ for pines across sites, and individuals at the BTB site had the highest ratio $(0.88 \pm 0.06)$ followed by individuals at the SL site $(0.54 \pm$ $0.07)$ and individuals at the $\mathrm{CB}$ site $(0.49 \pm 0.02)$, which were not significantly different $(P=0.85)$ from one another. Pines in all sites exhibited significant positive relationships between canopy stomatal conductance and soil moisture measured in the top $30 \mathrm{~cm}$, while only $Q$. velutina exhibited a positive relationship $(P<0.001)$ for the measured oak species (Figures 6C,D). For pines, individuals at the SL site had the largest slope for the relationship between soil moisture and canopy stomatal conductance, followed by pines at the BTB site and pines at the $\mathrm{CB}$ site which had the lowest slope term (Figure 6D). The relationship between stomatal sensitivity to VPD $\left(\delta \mathrm{G}_{\mathrm{S}} / \delta \ln \mathrm{VPD}\right)$ and relative soil moisture content was not significant for any oak species (Figure 7A), however pines at all study sites exhibited significant positive relationships (Figure 7B), with pines at the SL site having the highest slope term, followed by pines at the $\mathrm{BTB}$ site and pines at the CB site. In contrast, all oak species exhibited significant negative relationships between stomatal sensitivity to VPD and daily PPFD (Figure 7C) while only pines at the BTB site exhibited a significant negative relationship $(P=0.001$; Figure 7D). For oak species, $Q$. velutina exhibited a greater negative slope term, followed by $Q$. alba and Q. prinus which both exhibited similar slope terms.

\section{Discussion}

In an ecosystem where both water and nutrients are limiting, we found that oaks and pines exhibited differing strategies for resource acquisition and resource-use efficiency. In terms of water use, oaks had higher transpiration rates and stomatal 


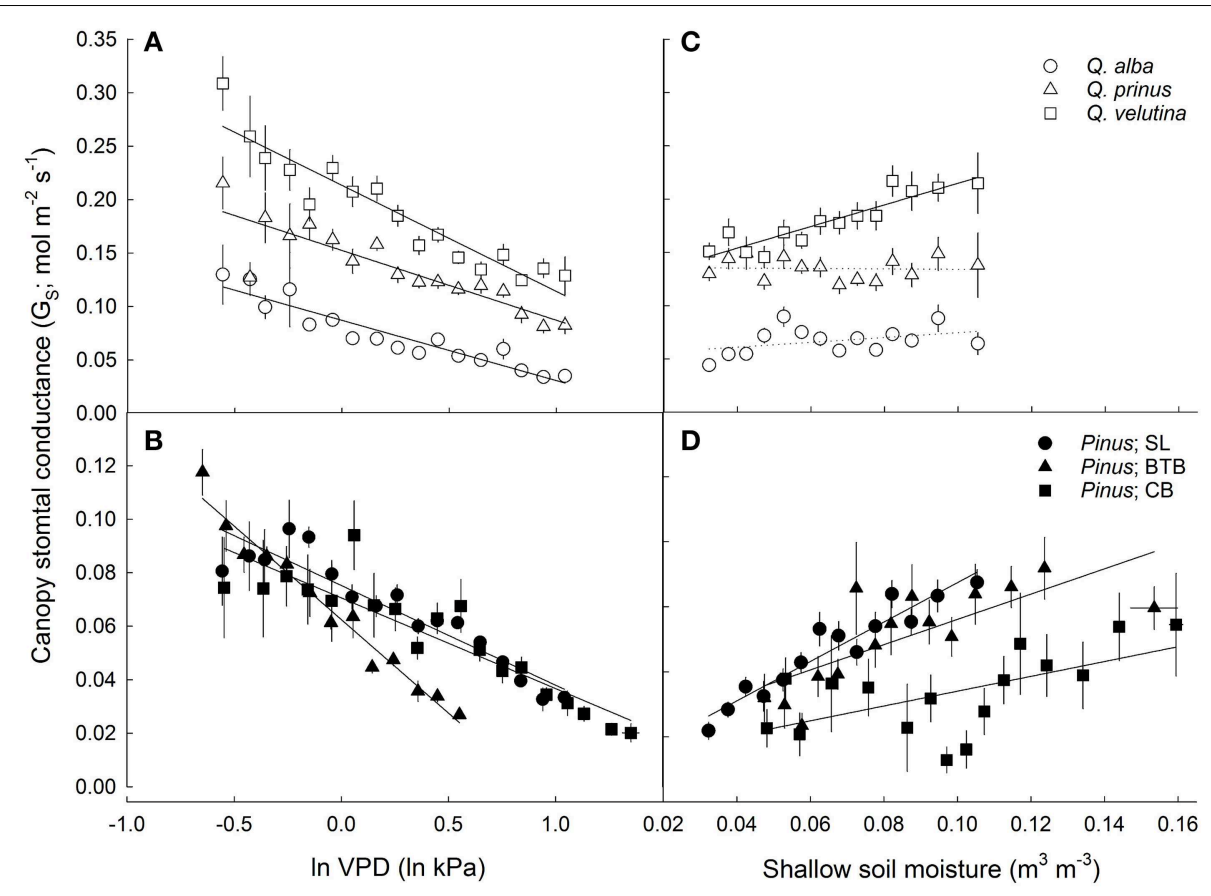

FIGURE 6 | Average daytime canopy stomatal conductance $\left(\mathrm{G}_{\mathrm{S}}\right.$; mol $\mathrm{m}^{-2} \mathrm{~s}^{-1}$; mean $\pm \mathrm{SE}$ across all individuals in each site/species category) vs. natural log-transformed average daytime vapor pressure deficit (InVPD; kPa) for (A) oaks including $Q$. alba $\left(y=-0.056 x+0.087 ; r^{2}=0.88\right)$, Q. prinus $\left(y=-0.065 x+0.15 ; r^{2}=0.78\right)$ and $Q$. velutina $(y=-0.099 x+0.21$; $\left.r^{2}=0.89\right)$ and (B) pines at the SL site $(y=-0.037 x+0.075$; $\left.r^{2}=0.88\right)$ the BTB site $\left(y=-0.070 x+0.063 ; r^{2}=0.97\right)$ and the CB site $\left(y=-0.034 x+0.071 ; r^{2}=0.82\right) . G_{S}$ vs. soil moisture in the top $30 \mathrm{~cm}\left(\mathrm{~m}^{3} \mathrm{~m}^{-3}\right)$ for (C) oaks including $Q$. alba (ns; $\left.P=0.12\right), Q$. prinus (ns; $P=0.54)$ and $Q$. velutina $\left(y=1.01 \mathrm{x}+0.11 ; r^{2}=0.84\right)$ and for (D) pines at the SL site $\left(y=0.61 \mathrm{x}+0.027 ; r^{2}=0.91\right)$, the BTB site $\left(y=0.39 x+0.037 ; r^{2}=0.57\right)$ and the CB site $(y=0.23 x+$ $0.031 ; r^{2}=0.36$ ). Solid lines represent significant relationships (slope $P<0.05$ ); dotted lines represent non-significant relationships (slope $P>0.05)$. conductances per unit leaf area compared with pines, while pines had greater water use efficiency based on gas exchange data. This confirms our hypothesis and could suggest that the large vessels of oaks are needed to overcome the frictional path length hydraulic resistance of pulling water from deeper groundwater sources. These results differ from the findings of Guehl et al. (1995) who found that Quercus robur L. had higher iWUE than Pinus pinaster Aiton when derived from either gas exchange or stable isotopes. However, we found that while pines had significantly higher WUE based on instantaneous gas exchange data, iWUE estimated via carbon isotope data did not differ significantly between oaks and pines. In contrast to water usage during the summer, for nutrients, particularly nitrogen, oaks had lower $\mathrm{N}$ per unit leaf area than pines as well as lower total leaf areas, but had higher photosynthetic $\mathrm{N}$ use efficiencies. Based on leaf lifespans, we expected pines to have greater PNUE as Wright et al. (2004) predict that longer-lived leaves should have lower photosynthetic assimilation rates, lower $\mathrm{N}_{\text {area }}$ and higher LMA than shorterlived leaves. We did find that pine needles had higher LMA than oaks, but they also had statistically similar $A_{\max }$ and greater $\mathrm{N}_{\text {area }}$ than oak leaves. Therefore, oaks appear to have greater access to water while pines have greater access to $\mathrm{N}$ (or more efficient reallocation of $\mathrm{N}$ ). This may reflect different rooting strategies with oaks being more deeply rooted to access stable sources of groundwater, while pines may have more shallow roots to access $\mathrm{N}$ released from the decomposing litter layer.

Across genera, we found a trade-off between using water and using nutrients efficiently possibly due to the spatial segregation between these two resources with stable water sources found in the deeper groundwater while nutrients are found in the litter layer on the soil surface. On the other hand, within genera, pines but not oaks, exhibited a significant relationship between iWUE and PNUE (Figure 5). Guehl et al. (1995) also found that WUE was strongly affected by $\mathrm{N}$ content in pines but not in oaks. This could suggest that evergreen leaf habit and/or large LMA could elicit trade-offs between PNUE and iWUE possibly due to the larger impact of mesophyll conductance in leaves with high LMA (Wright et al., 2004). In terms of access to water, Broeckx et al. (2014) found that short rotation poplar exhibited a trade-off between WUE and PNUE only during conditions of limiting soil moisture. Field et al. (1983) theorize that a tradeoff between NUE and WUE should exist across ecosystems along a moisture gradient with plants in dry ecosystems conserving water through lower stomatal conductance and increased WUE at the expense of NUE and plants in wetter ecosystems maximizing NUE with higher rates 


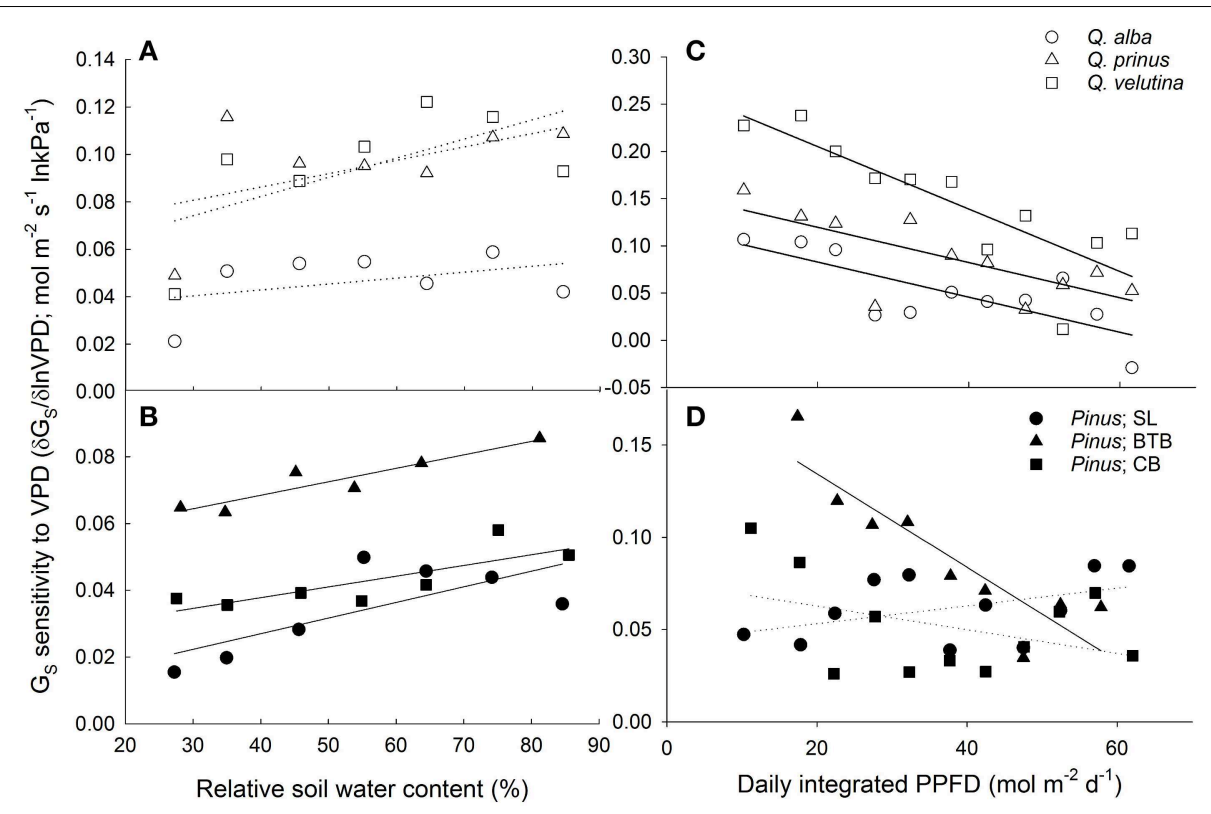

FIGURE 7 | Canopy stomatal conductance $\left(\mathrm{G}_{\mathrm{S}}\right)$ sensitivity to VPD $\left(\mathrm{mol} \mathrm{m}^{-2} \mathrm{~s}^{-1}\right.$ In $\mathrm{kPa}^{-1}$ ) defined as the negative slope of the relationship between $\mathrm{G}_{S}$ and InVPD vs. relative soil moisture content (\%) for (A) oaks including Q. alba (ns; $P=0.36$ ), Q. prinus (ns; $P=0.22$ ) and $Q$. velutina (ns; $P=0.13$ ) and for (B) pines at the SL site $\left(y=4.7 \times 10^{-4} \mathrm{X}+0.0083 ; r^{2}=0.53\right)$ the BTB site $\left(y=4.03 \times 10^{-4} \mathrm{X}+\right.$ $\left.0.0052 ; r^{2}=0.87\right)$, and the CB site $\left(y=3.2 \times 10^{-4} \times+0.025 ; r^{2}=0.65\right)$.
$G_{S}$ sensitivity to VPD vs. daily integrated photosynthetic photon flux density (PPFD; mol photons $\mathrm{m}^{-2} \mathrm{~d}^{-1}$ ) for (C) oaks including $Q$. alba $(y=$ $\left.-0.0019 x+0.12 ; r^{2}=0.59\right)$, Q. prinus $\left(y=-0.0019 x+0.16 ; r^{2}=0.54\right)$ and Q. velutina $\left(y=-0.0033 x+0.27 ; r^{2}=0.71\right)$ and for (D) pines at the $S L$ site (ns; $P=0.17)$, the BTB site $\left(y=-0.0025 \mathrm{x}+0.19 ; r^{2}=0.8\right)$ and the CB site (ns; $P=0.22$ ). Solid lines represent significant relationships (slope $P<0.05$ ); dotted lines represent non-significant relationships (slope $P>0.05$ ). of stomatal conductance, and hence, greater water use and lower WUE. This could suggest that co-occurring pines in this study have differing access to water, within and across sites, thereby displaying a tradeoff between WUE and PNUE. Oaks, on the other hand, may only occur in locations where they can access groundwater, and therefore do not exhibit a relationship between WUE and PNUE. However, while oaks exhibited higher PNUE and pines exhibited higher WUE, we found that the relationships between various physiological parameters and these resourceuse efficiency estimates were largely similar between the two cooccurring genera. Oaks and pines displayed similar slopes in the linear regression relationships between $\mathrm{iWUE}_{\text {inst. }}$ and $\mathrm{A}_{\text {net }}$ and $\mathrm{g}_{\mathrm{s}}$ (Figure 3) as well as between PNUE and $A_{\text {net }}$, LMA, and $\mathrm{N}_{\text {area }}$ (Figure 4).

The other main objective of this study was to compare canopy stomatal conductance response to environmental drivers between oaks and pines. Oaks tended to have higher negative slope terms in the relationship between $\operatorname{lnVPD}$ and canopy stomatal conductance $\left(\delta G_{S} / \delta\right.$ ln VPD; Figures 6A,B) suggesting greater stomatal sensitivity to VPD. This differs from the findings of Kolb and Stone (2000) who found that stomatal conductance of ponderosa pine (Pinus ponderosa Douglas ex C. Lawson) was more sensitive to VPD than Gambel oak (Quercus gambelii Nutt.). However, when these slope terms were scaled by reference stomatal conductance at VPD $=1 \mathrm{kPa}$, $\left(\mathrm{G}_{\text {Sref }}\right)$, these stomatal sensitivity ratios were significantly lower in oaks compared with pines. We expected that oaks would exhibit more anisohydric stomatal behavior and therefore exhibit lower stomatal sensitivities compared with pines. However, differences were largely driven by the high stomatal sensitivity ratios measured in pines at the $\mathrm{BTB}$ site, and when this site was excluded, stomatal sensitivity ratios are not significantly different $(P=0.13)$ between oaks and pines. A similar stomatal sensitivity between oaks and pines is in accordance with findings of Martínez-Vilalta et al. (2014) who found both oaks and pines to be partially isohydric based on relationships between predawn and midday leaf water potentials. Oren et al. (1999) report an average stomatal sensitivity ratio across tree and ecosystem types of around 0.6 , which is consistent with theory and equations of stomatal optimization presented by Katul et al. (2009). Stomatal sensitivity ratios of pines in this study when all sites were included did not differ significantly from this 0.6 value $(P=0.06)$, but were significantly lower $(P=0.002)$ when individuals from the BTB site were excluded. Likewise, oaks from all measured species in this study had stomatal sensitivity ratios that were significantly lower $(P=$ 0.04 ) than the 0.6 value. A stomatal sensitivity ratio lower than 0.6 was also seen in older Picea mariana [(Mill.) Britton, Sterns and Poggenburg (Ewers et al., 2005)], desert creosotebush [Larrea tridentata (DC.) Coville] (Ogle and Reynolds, 2002) and three oak species (Q. prinus L., Q. alba L., and Q. rubra L.) growing in Central Pennsylvania (Meinzer et al., 2013). For oaks and pines growing in the New Jersey Pinelands, a lower stomatal sensitivity ratio may reflect access to deeper sources of 
stable water decreasing the sensitivity to atmospheric moisture stress.

Although both oaks and pines in this study appear to have access to a stable source of groundwater, we did find a positive relationship between soil moisture in the upper $30 \mathrm{~cm}$ and average canopy stomatal conductance in pines from all sites but only in Q. velutina among the measured oak species (Figures 6C,D). Similar results have been reported from other pine-oak systems by Zweifel et al. (2007) and Poyatos et al. (2008), who found that the stomata of Scots pine (Pinus sylvestris L.) were more sensitive to drought than pubescent oak (Q. pubescens Willd.) and Eilmann et al. (2009) who found that growth in Scots pine was more dependent on water availability than oaks. Likewise, Kolb and Stone (2000) found that oaks in the Southwestern U.S. had higher predawn leaf water potentials than pines suggesting reliable access to deeper water. Both Q. prinus and Q. alba showed no relationship between canopy stomatal conductance and shallow soil moisture, which suggests that pines have more shallow roots than oaks and are more affected by surface water stress. Differences in source water $\delta^{18} \mathrm{O}$ from oaks and pines at the SL site also indicate differences in rooting depth between pines and oaks and between Q. prinus and Q. velutina (Song et al., 2014) as suggested by the stomatal conductance data presented in this study. Likewise, pines at all sites exhibited significant positive relationships between stomatal sensitivity to VPD and relative soil water content, while for oak species, none of the relationships were significant (Figures 7A,B). The lower stomatal sensitivity at lower relative soil water content seen in pines is likely the result of decreased reference stomatal conductance rates during drought conditions (Domec et al., 2009). In contrast, all oak species exhibited significant negative relationships between stomatal sensitivity to VPD and daily PPFD, while only pines at the BTB site exhibited a significant negative relationship (Figures 7 C,D). Therefore, stomatal responses to VPD were more affected by energy availability than soil moisture in oaks, while the opposite was true for pines.

Our results at the leaf- and individual tree-level can also be compared with ecosystem measurements to better understand how estimates of plant function compare across scales. On a per unit leaf area basis, oaks, and pines had similar maximum photosynthetic assimilation rates while oaks had greater stomatal conductance. On a tree-level basis, pines had greater leaf areas and whole-canopy transpiration rates $\left(\mathrm{E}_{\mathrm{C}}\right)$, while oaks had greater leaf-specific transpiration rates $\left(\mathrm{E}_{\mathrm{L}}\right)$ and average canopy stomatal conductances. Interestingly, when comparing stomatal conductances between oak and pines, they differed by about $0.1 \mathrm{~mol} \mathrm{~m}^{-2} \mathrm{~s}^{-1}$ both in leaf-level stomatal conductance estimates and in canopy-level integrated estimates. Across study sites, pines at the BTB site displayed differing physiological responses to environmental drivers (particularly VPD and PPFD) as well as lower iWUE based on carbon isotopes compared with the other sites (SL and CB) that were more similar to one another. This is interesting given that the SL and CB sites are oak-dominated and pine-dominated respectively and the BTB site occurs between the other sites on a latitudinal gradient.
Therefore, we can detect no inherent biologic or edaphic features that would explain the differences in pines at the BTB site compared with the other two sites. In terms of stand-level measurements, eddy covariance data from the "SL" oak stand and the "CB" pine stand found that annual gross ecosystem productivity (GEP) was higher in the pine stand, while daily summer GEP, net ecosystem exchange, and ecosystem water use efficiency were higher in the oak stand (Clark et al., 2014). Likewise, we found that iWUE based on carbon isotopes, which is a more temporally integrated measure, was somewhat higher (but not significantly so) in oaks compared with pines even though instantaneous WUE was greater in pines. The different interpretation of WUE at different spatial and temporal scales is likely due to several factors including differences in leaf area and leaf habit with pines assimilating more carbon in the spring and fall which occurs at a lower WUE (Clark et al., 2014) and in an atmosphere with a different carbon isotopic composition than the summer, lowering the iWUE estimate based on carbon isotopes for pines relative to instantaneous, summer values. In terms of total ecosystem water use, daily summer evapotranspiration (ET) rates were similar in oak and pine stands, but annual rates were greater in the pine stand (Clark et al., 2012) likely due to differences in leaf area display whereby evergreen needles increase rainfall interception losses, and therefore, evaporation rates, as well as transpiring in the winter. Therefore, differences in stand basal area, understory function, and the proportion of evaporation to transpiration in ET affect scaling of physiological functioning from the leaf to tree to ecosystem level.

In total, these results can inform predictions of forest function in terms of water use and carbon sequestration given changes in climate and/or changes in species composition as a result of disturbance events that preferentially target oaks or pines. Disturbance is important in many pine-oak ecosystems with both genera being susceptible to wildfire, but each having species with the ability to resprout following fire. Invasive insects can also differentially affect oaks and pines. Gypsy moths and other defoliators tend to preferentially target oaks and other broadleaved species while many bark beetles specifically target pine species. Several studies have reported predictions of climate change effects on pine-oak ecosystems in Mexico (GómezMendoza and Arriaga, 2007) and the Alps (Weber et al., 2007) suggesting that pines were more vulnerable to drought stress than oaks. Our study also suggests that canopy stomatal conductance in pines is more negatively affected by decreases in precipitation and soil moisture as well as increases in temperature and VPD. In contrast, oaks in our study show greater stomatal sensitivity to changes in energy availability in terms of PPFD and cloud cover, and are less negatively affected by drought stress. Changes in nutrient cycling, particularly in terms of $\mathrm{N}$, should also have a large impact on productivity of forests in the New Jersey Pinelands. For other sandy soil ecosystems, fertilization has been shown to have a larger effect on productivity via increases in leaf area compared to irrigation alone (Albaugh et al., 1998; Ewers et al., 1999) suggesting that trees in these sites are primarily nutrient-limited and may not experience frequent drought stress. In terms of species-specific differences in the New Jersey Pinelands, our study suggests that oaks will be more positively 
affected by nutrient additions to the ecosystem compared with pines. In terms of increasing atmospheric $\mathrm{CO}_{2}$ concentrations, productivity in pines should be more positively affected compared with oaks due to their stomatal sensitivity to soil and atmospheric moisture deficits. In total, these results on resource acquisition and trade-offs between water- and photosynthetic $\mathrm{N}$ use efficiency can inform how oaks and pines function within a given ecosystem, their spatial distribution within the larger landscape, and their potential responses to future environmental change.

\section{Author Contributions}

HJR analyzed data and wrote the manuscript, NJC performed data acquisition and manuscript editing, KLC provided data and comments on manuscript, and KVRS provided comments on the

\section{References}

Albaugh, T., Allen, H., Dougherty, P., Kress, L., and King, J. (1998). Leaf area and above- and belowground growth responses of loblolly pine to nutrient and water additions. For. Sci. 44, 317-328.

Bockheim, J. G., and Leide, J. E. (1991). Foliar nutrient dynamics and nutrient-use efficiency of oak and pine on a low-fertility soil in Wisconsin. Can. J. For. Res. 21, 925-934. doi: 10.1139/x91-128

Broeckx, L., Fichot, R., Verlinden, M., and Ceulemans, R. (2014). Seasonal variations in photosynthesis, intrinsic water-use efficiency and stable isotope composition of poplar leaves in a short-rotation plantation. Tree Physiol. 34, 701-715. doi: 10.1093/treephys/tpu057

Bush, S. E., Hultine, K. R., Sperry, J. S., and Ehleringer, J. R. (2010). Calibration of thermal dissipation sap flow probes for ring- and diffuse-porous trees. Tree Physiol. 30, 1545-1554. doi: 10.1093/treephys/tpq096

Cavender-Bares, J., and Bazzaz, F. A. (2000). Changes in drought response strategies with ontogeny in Quercus rubra: implications for scaling from seedlings to mature trees. Oecologia 124, 8-18. doi: 10.1007/PL000 08865

Choat, B., Jansen, S., Brodribb, T. J., Cochard, H., Delzon, S., Bhaskar, R., et al. (2012). Global convergence in the vulnerability of forests to drought. Nature 491, 752-755. doi: 10.1038/nature11688

Clark, K. L., Skowronski, N., Gallagher, M., Renninger, H., and Schäfer, K. (2012). Effects of invasive insects and fire on forest energy exchange and evapotranspiration in the New Jersey Pinelands. Agric. For. Meteorol. 166-167, 50-61. doi: 10.1016/j.agrformet.2012.07.007

Clark, K. L., Skowronski, N. S., Gallagher, M. R., Renninger, H. R., and Schäfer, K. V. R. (2014). Contrasting effects of invasive insects and fire on ecosystem water use efficiency. Biogeosciences 11, 6509-6523. doi: 10.5194/bg-116509-2014

Collatz, G. J., Ball, J. T., Grivet, C., and Berry, J. A. (1991). Physiological and environmental regulation of stomatal conductance, photosynthesis and transpiration: a model that includes a laminar boundary layer. Agric. For. Meteorol. 54, 107-136. doi: 10.1016/0168-1923(91)90002-8

DeLucia, E. H., and Schlesinger, W. H. (1991). Resource-use efficiency and drought tolerance in adjacent great basin and sierran plants. Ecology 72, 51-58. doi: $10.2307 / 1938901$

Díaz, L. (2006). Influences of forest type and forest structure on bird communities in oak and pine woodlands in Spain. For. Ecol. Manag. 223, 54-65. doi: 10.1016/j.foreco.2005.10.061

Domec, J. C., Noormets, A., King, J. S., Sun, G., McNulty, S. G., Gavazzi, M. J., et al. (2009). Decoupling the influence of leaf and root hydraulic conductances on stomatal conductance and its sensitivity to vapour pressure deficit as soil dries in a drained loblolly pine plantation. Plant Cell Environ. 32, 980-991. doi: 10.1111/j.1365-3040.2009.01981.x manuscript and the data analysis as well as funding, equipment, experimental design.

\section{Acknowledgments}

The authors thank K. St. Ange, B. Tsai and M. Taeda for preparing leaf isotope samples. This research was funded by a United States Department of Agriculture Forest Service joint venture agreement 10-JV-11242306-136 and Office of Science (BER), United States Department of Energy DE-SC0007041 to KVRS.

\section{Supplementary Material}

The Supplementary Material for this article can be found online at: http://journal.frontiersin.org/article/10.3389/fpls.2015. 00297/abstract

Eilmann, B., Zweifel, R., Buchmann, N., Fonti, P., and Rigling, A. (2009). Droughtinduced adaptation of the xylem in Scots pine and pubescent oak. Tree Physiol. 29, 1011-1020. doi: 10.1093/treephys/tpp035

Ewers, B. E., Gower, S., Bond-Lamberty, B., and Wang, C. K. (2005). Effects of stand age and tree species on canopy transpiration and average stomatal conductance of boreal forests. Plant Cell Environ. 28, 660-678. doi: 10.1111/j.1365-3040.2005.01312.x

Ewers, B. E., Oren, R., Albaugh, T., and Dougherty, P. M. (1999). Carryover effects of water and nutrient supply on water use of Pinus taeda. Ecol. Appl. 9, 513-525. doi: 10.1890/1051-0761(1999)009[0513:COEOWA] 2.0.CO;2

Ewers, B. E., Oren, R., Phillips, N., Strömgren, M., and Linder, S. (2001). Mean canopy stomatal conductance responses to water and nutrient availabilities in Picea abies and Pinus taeda. Tree Physiol. 21, 841-850. doi: 10.1093/treephys/21.12-13.841

Farquhar, G. D., Ehleringer, J. R., and Hubick, K. T. (1989). Carbon isotope discrimination and photosynthesis. Annu. Rev. Plant Physiol. Plant Mol. Biol. 40, 503-537. doi: 10.1146/annurev.pp.40.060189.002443

Farquhar, G. D., von Caemmerer, S., and Berry, J. A. (1980). A biochemical model of photosynthetic $\mathrm{CO}_{2}$ assimilation in leaves of $\mathrm{C}_{3}$ species. Planta 149, 78-90. doi: 10.1007/BF00386231

Field, C., Merino, J., and Mooney, H. A. (1983). Compromises between water-use efficiency and nitrogen-use efficiency in five species of California evergreens Oecologia 60, 384-389. doi: 10.1007/BF00376856

García-Barrios, L., and González-Espinosa, M. (2004). Change in oak to pine dominance in secondary forests may reduce shifting agriculture yields: experimental evidence from Chiapas, Mexico. Agric. Ecosyst. Environ. 102, 389-401. doi: 10.1016/j.agee.2003.08.013

Goff, J. A., and Gratch, S. (1946). Low-pressure properties of water from -160 to $212^{\circ}$ F. Trans. Am. Soc. Heat. Vent. Eng. 95-122.

Gómez-Mendoza, L., and Arriaga, L. (2007). Modeling the effect of climate change on the distribution of oak and pine species in Mexico. Conserv. Biol. 21, 1545-1555. doi: 10.1111/j.1523-1739.2007.00814.x

Granier, A. (1987). Evaluation of transpiration in a Douglas-fir stand by means of sap flow measurements. Tree Physiol. 3, 309-320. doi: 10.1093/treephys/ 3.4.309

Guehl, J. M., Fort, C., and Ferhi, A. (1995). Differential response of leaf conductance, carbon isotope discrimination and water-use efficiency to nitrogen deficiency in maritime pine and pedunculate oak plants. New Phytol. 131, 149-157. doi: 10.1111/j.1469-8137.1995.tb05716.x

Hothorn, T., Bretz, F., and Westfall, P. (2008). Simultaneous inference in general parametric models. Biom. J. 50, 346-363. doi: 10.1002/bimj.200810425

Hultine, K. R., Nagler, P. L., Morino, K., Bush, S. E., Burtch, K. G., Dennison, P. E., et al. (2010). Sap flux-scaled transpiration by tamarisk (Tamarix spp.) before, during and after episodic defoliation by the saltcedar leaf 
beetle (Diorhabda carinulata). Agric. For. Meteorol. 150, 1467-1475. doi: 10.1016/j.agrformet.2010.07.009

Katul, G., Palmroth, S., and Oren, R. (2009). Leaf stomatal responses to vapour pressure deficit under current and $\mathrm{CO}_{2}$-enriched atmosphere explained by the economics of gas exchange. Plant Cell Environ. 32, 968-979. doi: 10.1111/j.1365-3040.2009.01977.x

Klein, T., Shpringer, I., Fikler, B., Elbaz, G., Cohen, S., and Yakir, D. (2013). Relationships between stomatal regulation, water use, and water-use efficiency of two co-existing key Mediterranean tree species. For. Ecol. Manag. 302, 34-42. doi: 10.1016/j.foreco.2013.03.044

Kolb, T., and Stone, J. (2000). Differences in leaf gas exchange and water relations among species and tree sizes in an Arizona pine-oak forest. Tree Physiol. 20, 1-12. doi: 10.1093/treephys/20.1.1

Köstner, B., Schulze, E., Kelliher, F., Hollinger, D., Byers, J., Hunt, J., et al. (1992). Transpiration and canopy conductance in a pristine broad-leaved forest of Nothofagus: an analysis of xylem sap flow and eddy correlation measurements. Oecologia 91, 350-359. doi: 10.1007/BF00317623

Lathrop, R., and Kaplan, M. B. (2004). New Jersey Land Use/Land Cover Update: 2000-2001. Trenton, NJ: New Jersey Department of Environmental Protection.

Ledig, F., and Little, S. (1979). "Pitch Pine (Pinus rigida Mill.): ecology, physiology and genetics," in Pine Barrens: Ecosystem and Landscape, ed R. T. T. Forman (New York, NY: Academic Press, Inc.), 347-368.

Leuning, R. (1990). Modelling stomatal behaviour and photosynthesis of Eucalyptus grandis. Aust. J. Plant Physiol. 17, 159-175. doi: 10.1071/PP99 00159

Little, S. (1979). "Fire and plant succession in the New Jersey Pine Barrens," in Pine Barrens: Ecosystem and Landscape, ed R. T. T. Forman (New York, NY: Academic Press), 297-314.

Lobo, F., de Barros, M., Dalmagro, H., Dalmolin, Â., de Souza, É., Vourlitis, G., et al. (2013). Fitting net photosynthetic light-response curves with Microsoft Excel - a critical look at the models. Photosynthetica 51, 445-456. doi: 10.1007/s11099-013-0045-y

Martínez-Vilalta, J., Poyatos, R., Aguadé, D., Retana, J., and Mencuccini, M. (2014). A new look at water transport regulation in plants. New Phytol. 204, 105-115. doi: $10.1111 / \mathrm{nph} .12912$

McCulloh, K. A., Sperry, J. S., Lachenbruch, B., Meinzer, F. C., Reich, P. B., and Voelker, S. (2010). Moving water well: comparing hydraulic efficiency in twigs and trunks of coniferous, ring-porous, and diffuse-porous saplings from temperate and tropical forests. New Phytol. 186, 439-450. doi: 10.1111/j.14698137.2010.03181.x

Meinzer, F. C., Woodruff, D. R., Eissenstat, D., Lin, H., Adams, T., and McCulloh, K. A. (2013). Above- and belowground controls on water use by trees of different wood types in an eastern US deciduous forest. Tree Physiol. 33, 345-356. doi: 10.1093/treephys/tpt012

Nabeshima, E., and Hiura, T. (2004). Size dependency of photosynthetic water- and nitrogen-use efficiency and hydraulic limitation in Acer mono. Tree Physiol. 24, 745-752. doi: 10.1093/treephys/24.7.745

Neill, C., Patterson, W. A. III, and Crary, D.W. Jr. (2007). Responses of soil carbon, nitrogen and cations to the frequency and seasonality of prescribed burning in a Cape Cod oak-pine forest. For. Ecol. Manage. 250, 234-243. doi: 10.1016/j.foreco.2007.05.023

Nixon, K. (2006). "Global and neotropical distribution and diversity of oak (genus Quercus) and oak forests," in Ecology and Conservation of Neotropical Montane Oak Forests, ed M. Kappelle (Berlin: Springer-Verlag), 3-13.

Nowacki, G. J., and Abrams, M. D. (2008). The demise of fire and "mesophication" of forests in the Eastern United States. Bioscience 58, 123-138. doi: $10.1641 /$ B580207

Ogle, K., and Reynolds, J. (2002). Desert dogma revisited: coupling of stomatal conductance and photosynthesis in the desert shrub, Larrea tridentata. Plant Cell Environ. 25, 909-921. doi: 10.1046/j.1365-3040.2002.00876.x

Oishi, A. C., Oren, R., and Stoy, P. C. (2008). Estimating components of forest evapotranspiration: a footprint approach for scaling sap flux measurements. Agric. For. Meteorol. 148, 1719-1732. doi: 10.1016/j.agrformet.2008.06.013

Oren, R., Sperry, J. S., Katul, G. G., Pataki, D. E., Ewers, B. E., Phillips, N., et al. (1999). Survey and synthesis of intra- and interspecific variation in stomatal sensitivity to vapour pressure deficit. Plant Cell Environ. 22, 1515-1526. doi: 10.1046/j.1365-3040.1999.00513.x
Parshall, T., Foster, D., Faison, E., MacDonald, D., and Hansen, B. (2003). Long-term history of vegetation and fire in pitch pine-oak forests on Cape Cod, Massachusetts. Ecology 84, 736-748. doi: 10.1890/0012-9658(2003)084[0736:LTHOVA]2.0.CO;2

Phillips, N., Bond, B. J., McDowell, N. G., Ryan, M. G., and Schauer, A. (2003). Leaf area compounds height-related hydraulic costs of water transport in Oregon white oak trees. Funct. Ecol. 17, 832-840. doi: 10.1111/j.13652435.2003.00791.x

Phillips, N., Nagchaudhuri, A., Oren, R., and Katul, G. (1997). Time constant for water transport in loblolly pine trees estimated from time series of evaporative demand and stem sapflow. Trees 11,412-419. doi: 10.1007/s004680 050102

Phillips, N., and Oren, R. (1998). A comparison of daily representations of canopy conductance based on two conditional time-averaging methods and the dependance of daily conductance on environmental factors. Ann. For. Sci. 55, 217-235. doi: 10.1051/forest:19980113

Pinheiro, J., Bates, D., DebRoy, S., and Sarkar, D. (2014). nlme: Linear and Nonlinear Mixed Effects Models. R Package Version 3.1-118. Available online at: http://CRAN.R-project.org/package=nlme

Poyatos, R., Llorens, P., Piñol, J., and Rubio, C. (2008). Response of Scots pine (Pinus sylvestris L.) and pubescent oak (Quercus pubescens Willd.) to soil and atmospheric water deficits under Mediterranean mountain climate. Ann. For. Sci. 65, 306. doi: 10.1051/forest:2008003

Prioul, J., and Chartier, P. (1977). Partitioning of transfer and carboxylation components of intracellular resistance to photosynthetic $\mathrm{CO}_{2}$ fixation: a critical analysis of the methods used. Ann. Bot. 41, 789-800.

Renninger, H. J., Carlo, N., Clark, K. L., and Schäfer, K. V. R. (2014). Physiological strategies of co-occurring oaks in a water- and nutrient-limited ecosystem. Tree Physiol. 34, 159-173 doi: 10.1093/treephys/tpt122

Renninger, H. J., and Schäfer, K. V. R. (2012). Comparison of tissue heat balanceand thermal dissipation-derived sap flow measurement in ring-porous oaks and a pine. Front. Plant Sci. 3:103. doi: 10.3389/fpls.2012.00103

Renninger, H. J., Schäfer, K. V. R., Clark, K. L., and Skowronski, N. (2013). Effects of a prescribed fire on water use and photosynthetic capacity of pitch pines. Trees 27, 1115-1127. doi: 10.1007/s00468-013-0861-5

Richardson, D., and Rundel, P. (1998). "Ecology and biogeography of Pinus: an introduction," in Ecology and Biogeography of Pinus, ed D. Richardson (Cambridge: Cambridge University Press), 3-40.

Rogers, R., and Hinckley, T. (1979). Foliar weight and area related to current sapwood area in oak. For. Sci. 25, 298-303.

Schäfer, K., Clark, K. L., Skowronski, N., and Hamerlynck, E. P. (2010). Impact of insect defoliation on forest carbon balance as assessed with a canopy assimilation model. Glob. Change Biol. 16, 546-560. doi: 10.1111/j.13652486.2009.02037.x

Schäfer, K., Renninger, H., Clark, K., and Medvigy, D. (2014). Hydrological responses to defoliation and drought of an upland oak/pine forest. Hydrol. Process. 28, 6113-6123. doi: 10.1002/hyp.10104

Schäfer, K. V. R. (2011). Canopy stomatal conductance following drought, disturbance and death in an upland oak/pine forest of the New Jersey Pine Barrens, USA. Front. Plant Sci. 2:15. doi: 10.3389/fpls.2011.00015

Scheller, R., Van Tuyl, S., Clark, K., Hayden, N., Hom, J., and Mladenoff, D. (2008). Simulation of forest change in the New Jersey Pine Barrens under current and pre-colonial conditions. For. Ecol. Manag. 255, 1489-1500. doi: 10.1016/j.foreco.2007.11.025

Sharkey, T. D., Bernacchi, C., Farquhar, G. D., and Singsaas, E. (2007). Fitting photosynthetic carbon dioxide response curves for C3 leaves. Plant Cell Environ. 30, 1035-1040. doi: 10.1111/j.1365-3040.2007.01710.x

Sheng, W., Ren, S., Yu, G., Fang, H., Jiang, C., and Zhang, M. (2011). Patterns and driving factors of WUE and NUE in natural forest ecosystems along the North-South Transect of Eastern China. J. Geogr. Sci. 21, 651-665. doi: 10.1007/s11442-011-0870-5

Skowronski, N., Clark, K., Gallagher, M., Birdsey, R., and Hom, J. (2014). Airborne laser scanner-assisted estimation of aboveground biomass change in a temperate oak-pine forest. Remote Sens. Environ. 151, 166-174. doi: 10.1016/j.rse.2013.12.015

Song, X., Clark, K. S., and Helliker, B. R. (2014). Interpreting species-specific variation in tree-ring oxygen isotope ratios among three temperate forest trees. Plant Cell Environ. 37, 2169-2182. doi: 10.1111/pce.12317 
Sterck, F. J., Zweifel, R., Sass-Klaassen, U., and Chowdhury, Q. (2008). Persisting soil drought reduces leaf specific conductivity in Scots pine (Pinus sylvestris) and pubescent oak (Quercus pubescens). Tree Physiol. 28, 529-536. doi: 10.1093/treephys/28.4.529

Taneda, H., and Sperry, J. S. (2008). A case-study of water transport in co-occurring ring- versus diffuse-porous trees: contrasts in water-status, conducting capacity, cavitation and vessel refilling. Tree Physiol. 28, 1641-1651. doi: 10.1093/treephys/28.11.1641

Vose, J. M., Dougherty, P. M., Long, J. N., Smith, F. W., Gholz, H. L., and Curran, P. J. (1994). Factors influencing the amount and distribution of leaf area of pine stands. Ecol. Bull. 43, 102-114.

Weber, P., Bugmann, H., and Rigling, A. (2007). Radial growth responses to drought of Pinus sylvestris and Quercus pubescens in an innerAlpine dry valley. J. Veg. Sci. 18, 777-792. doi: 10.1111/j.1654-1103.2007. tb02594.x

Whittaker, R. H., and Woodwell, G. M. (1968). Dimension and production relations of trees and shrubs in the Brookhaven Forest, New York. J. Ecol. 56, 1-25. doi: $10.2307 / 2258063$
Wright, I. J., Reich, P. B., Westoby, M., Ackerly, D. D., Baruch, Z., Bongers, F., et al. (2004). The worldwide leaf economics spectrum. Nature 428, 821-827. doi: $10.1038 /$ nature 02403

Zweifel, R., Steppe, K., and Sterck, F. J. (2007). Stomatal regulation by microclimate and tree water relations: interpreting ecophysiological field data with a hydraulic plant model. J. Exp. Bot. 58, 2113-2131. doi: 10.1093/jxb/ erm050

Conflict of Interest Statement: The authors declare that the research was conducted in the absence of any commercial or financial relationships that could be construed as a potential conflict of interest.

Copyright (C) 2015 Renninger, Carlo, Clark and Schäfer. This is an open-access article distributed under the terms of the Creative Commons Attribution License (CC BY). The use, distribution or reproduction in other forums is permitted, provided the original author(s) or licensor are credited and that the original publication in this journal is cited, in accordance with accepted academic practice. No use, distribution or reproduction is permitted which does not comply with these terms. 